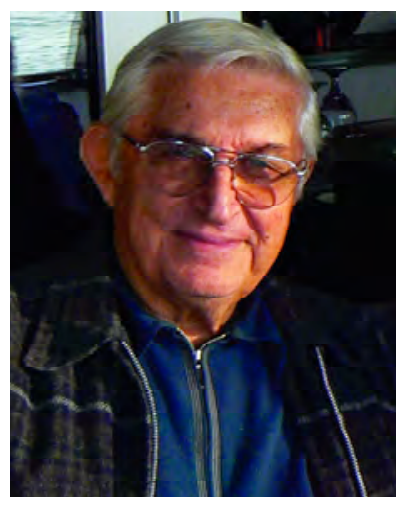

Prof. Gündüz Gökçe 1933'te İzmir Karşlyaka'da doğdu. Gazeteci-yazar Orhan Rahmi Gökçe'nin oğlu, gazeteci-yazar Zeynel Besim Sun'un torunudur. 1958'de bitirdiğgi D.G.S.A.Y. Mimarlık Bölümü'ne 1962'de Sedad H. Eldem'in asistanı olarak girdi. 1969'da doçent, 1978'de profesör oldu. Hocalığını hiç bırakmadan Anabilim Dalı ve Bölüm Başkanlıkları, Dekanlık, Rektör Yardımcıll̆̆g ve Rektörlük (2 Dönem) gibi idâri görevlerde bulundu. U.A.K. Sanat Dalları Konseyi Başkanlı̆̆ ve YÖK Genel Kurul Üyeliği yaptı. 2000'de emekli oldu.

Çeşitli mimari yarıșmalarda ödülleri, mansiyonları olan ve her zaman hocalı ̆̆ mimarlığın önünde tuttuğunu söyleyen Prof. Gökçe'ye, 2006 yllında

Mimarlık Ĕ̆itim Derneği MİMED tarafindan, "Mimarlı Eğitiminde Üstün Hizmet Ödülü” verildi. 2000 yılındaki emekliliğinin ardından Yeditepe Üniversitesi ve son olarak Işı Üniversitesi'nde görev yapan Prof. Gökçe, 2013-14 Ö ğretim Yll sonunda aktif ögrretim hayatını sonlandırmış bulunmaktadır.

I Bu metin, Mimar sinan Güzel Sanatlar Üniversitesi 2014-2015 Akademik Yıllı Açılıs Töreni'nde Prof. Gündüz Gökşe tarafindan açıs dersi olarak anlatılmıştır. Dordogna, Fransa MÖ $20.000^{\prime}$ ler.

\title{
Başlangıcından Günümüze Sanatın Gelişimine Kısa Bir Bakışl
}

Değerli konuklar, sayın Rektör, yöneticiler, sevgili öğrenciler hoş geldiniz...

Bugün 2014-2015 Eğitim-Öğretim Yılı'nın açılış dersini vermekten duyduğum mutluluğu belirtmek isterim. Burada sanatın gelişiminden söz edeceğim, başlangıçtan günümüze, görsel ve işitsel imkânlardan da yararlanarak. Bir ders süresi ile sınırlı olan konuşmada amacım, sanatın gelişim çizgisi ve bunun kırılma noktaları ile ilgili saptamalar yapmak, örnekler vermektir. Adeta "kuş bakışı" diyebileceğimiz bir yöntem ile.

Bugün sanatın öneminin, toplumların uluslararası değerlendirmelerinde ne derecede geçerli bir ölçüt olduğunun ülkemizde gerekli şekilde anlaşıldığını, ne yazık ki söyleyemiyoruz. Oysa bugün gelişmiş ülkeler, özellikle Avrupa ülkeleri, toplumun daha olumlu yönde eğitilmesinde, öncelikle çocukların okul öncesinden başlanarak, sanatla tanıştııılmasına yönelik “Melina Mercury Projesi”ni uygulama aşamasındalar.

Önce Kuzey İspanya'da, Altamira mağarasında 1879 'da bulunan tavanlara yapılmış resimlerle başlamak istiyorum. Bunlar ve daha sonra Lascaux ile diğer mağaralarda bulunan resimler, mağara duvarlarındaki rölyef tarzı kazıntılar, heykeli andıran objeler, günümüzden onbinlerce y1l öncesine, "Paleolitik" döneme tarihleniyordu. $\mathrm{Bu}$ o yılların, doğal mağaralarda barınan, beslenmesini toplayıcilık ve avcilıkla ancak sağlayabilen ilkel insanların sanat yaptığını gösteriyordu, ne amaçla, nasıl bir dürtüyle olursa olsun (Resim 1).

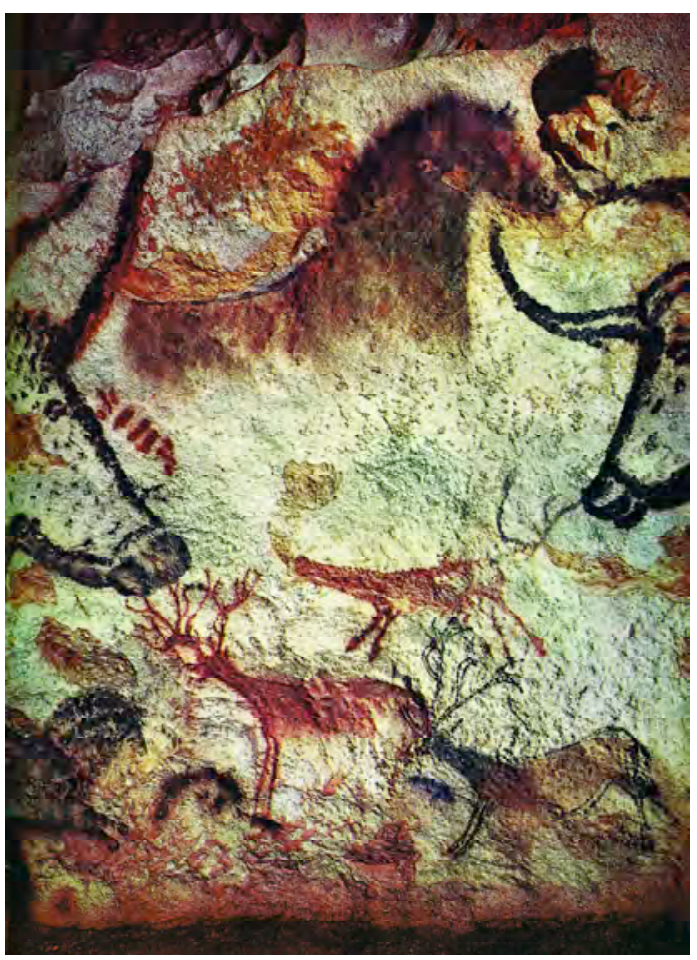



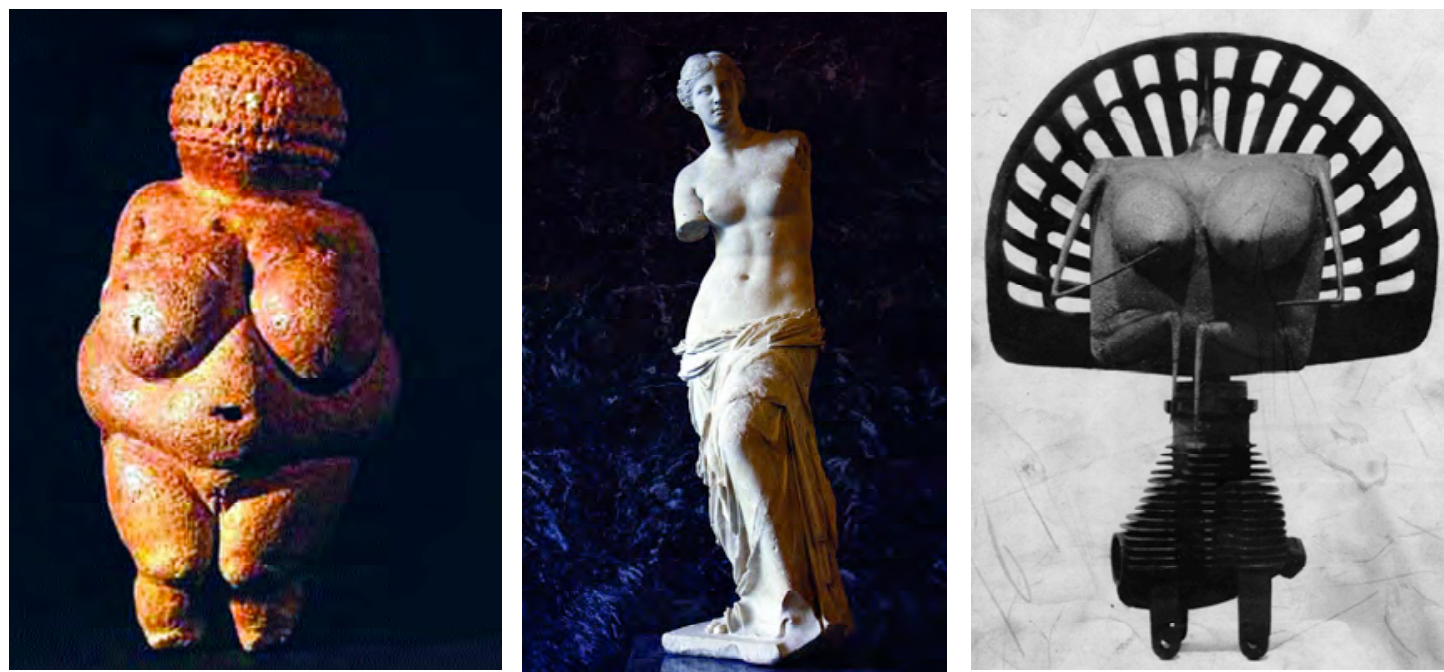

Resim: 2-4

Evet, sanat ilk insanla ortaya çıkmıştı, uygarlıklar, dönemler, akımlar boyu farklı bölgelerde, farklı faktörlere bağlı olarak, günümüze ulaşacaktı. Burada önce heykel, resim, müzik ve mimarlık dallarından üçer örnekle sanatın gelişmesini göstermek istiyorum, başlangıçtan günümüze, büyük aralıklarla. Önce kadın konusunda üç heykel: "Magdalenian" döneminden "Willendorf Venüs'ü", "Hellenistic" dönemden "Melos Venüs' ü" ve 20. yy. sonlarından Philippe Hiquiliy'den "Shanghay Venüs'ü" (Resim 2-4). Resme geçelim, önce Misır'dan, sonra 19. yy. ortalarından, Rosetti'den, sonra da Picasso'dan kadın portreleri (Resim 5-7). Müzikte de ABD Cheyenne'lerinden bir parçayı, sonra Rachmaninoff'un "Vocalise"ini ve 20. yy. başlarından Varese'nin "Hyperprism"ini dinleyelim. İzlediklerimiz açıkça görüldü̆gü gibi hep ileriye olan bir gelişmeyi göstermektedir. Mimarlıkta da öyle. Malzeme özelliklerine, statik kurallara, teknolojik imkânlara doğrudan bağlı olan mimarlıktan, doğal malzeme olarak ahşabın yer aldığı üç örneği düşünelim: Önce Rusya, Novgorod'dan 16. yy.'a ait bir kilise ve sonra da, İspanya'da Seville'den “Metropol Parasol" (Resim 8-9).

Gelişim gene ilerlemeye yönelik değil mi?

Resim: 5-7
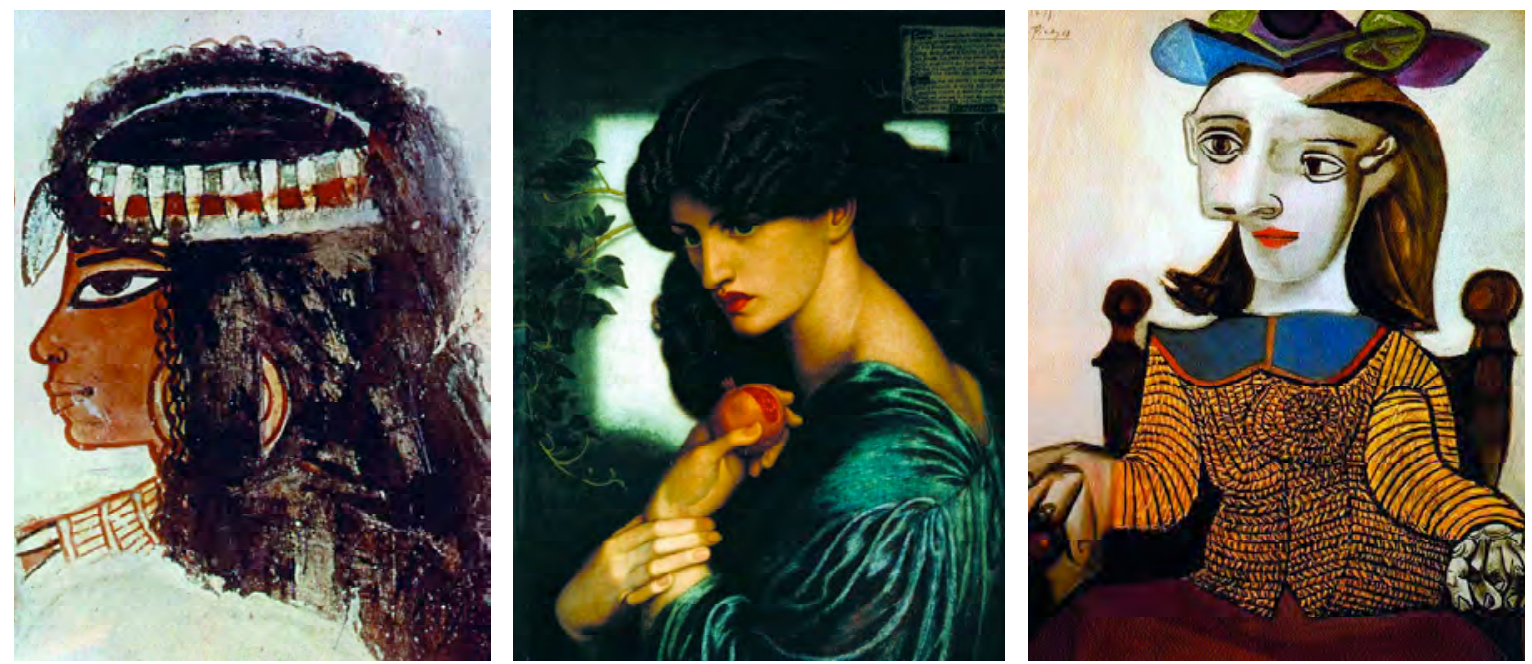

Resim: 2

Willendorf venüsü

Willendorf, Aşăı Avusturya,

MÖ 25.000'ler.

Resim: 3

Melos Venüsü

Melos Adası, Yunanistan, MÖ 130-100. Resim: 4

Shanghay Venüsü

1967, Philippe Hiquily.

Resim: 5

Antik Misir, Portre

MÖ 14-13. yy. Tutmosis IV Dönemi.

Resim: 6

Prosperine

874. Dante Gabriele Rosetti.

Resim: 7

Sarı Bluz (Dora Maar)

1939, Pablo Picasso. 


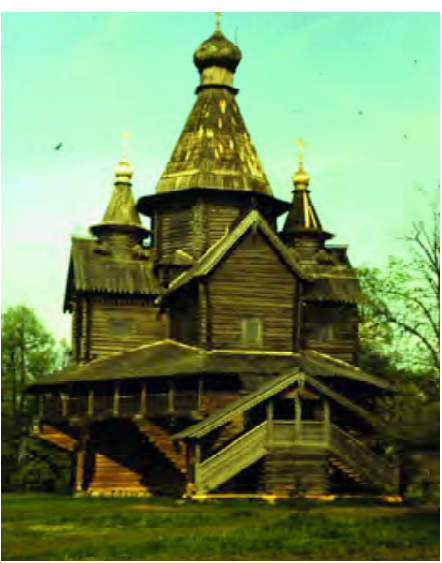

Resim: 8

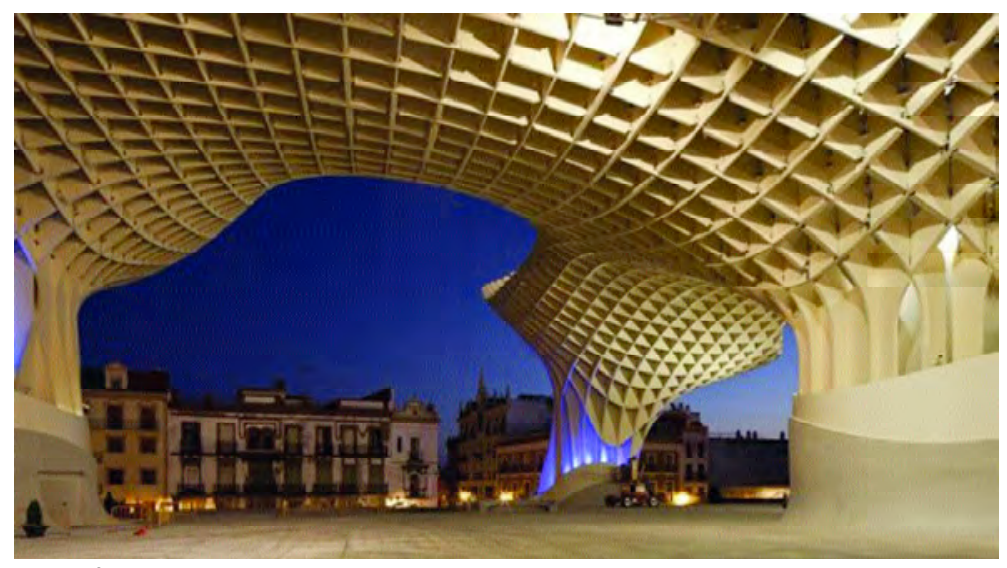

Resim: 9

Resim: 8 Şimdi Avrupa sanatının, çağlar boyu uygarlık, dönem ve akımlarına bağlı gelişimine, kutsal Bakirenin Doğus kilisesi yaşandığı zamanın ortamına hâkim koşullarına da kısa kısa değinerek örneklerle bakalım. Novgorod, 1699. Resim: 9 Metropol Parasol, seville
20ll, Jurgen Mayer.

"Batı Sanatı" dendiğinde akla ilk gelen Yunan ve Roma ile başlıyoruz: Antik Yunan Uygarlığı Ege coğrafyasında, başlangıcı Homeros öncesinin belirsizliklerine dayanan ve M.Ö. 146'daki Roma istilâsına kadar süren, Atina, Sparta, Thebai gibi şehir devletlerinden oluşan çok dinli, edebiyat alanında Euripides, Sofokles gibi edebiyatçılar, Aristo ve Sokrates gibi felsefeciler, matematikçiler yetiştirmiş bir uygarlıktır.

Sanat alanında günümüze ulaşabilen arkaik örnekler, "Kore" ve "Kuros" denen ilkel heykeller giderek Yunan sanatının "klasik" döneminde Myron, Praksiteles gibi sanatçılarla yüksek bir seviyeye ulaşmıştır. Burada, ileride Rönesans'ta Boticelli'nin “Venüs' ün Doğuşu”" adlı resmini ve esinlendiği açıç̧a belli olan Praksiteles'in “Knidas Venüs'ü”nü birlikte görüyoruz (Resim 10-11).

Venüsün Doğuşu

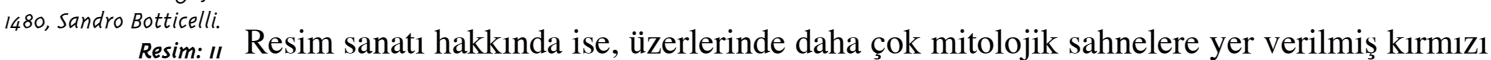
Knidas (Daţ̧a) Venüsü veya siyah figürlü, "krater", "hydria", "lekitos", "amfora" gibi pişmiş toprak kaplardan bilgi
Mö 4. yy., Praksiteles. sahibi olabiliyoruz.

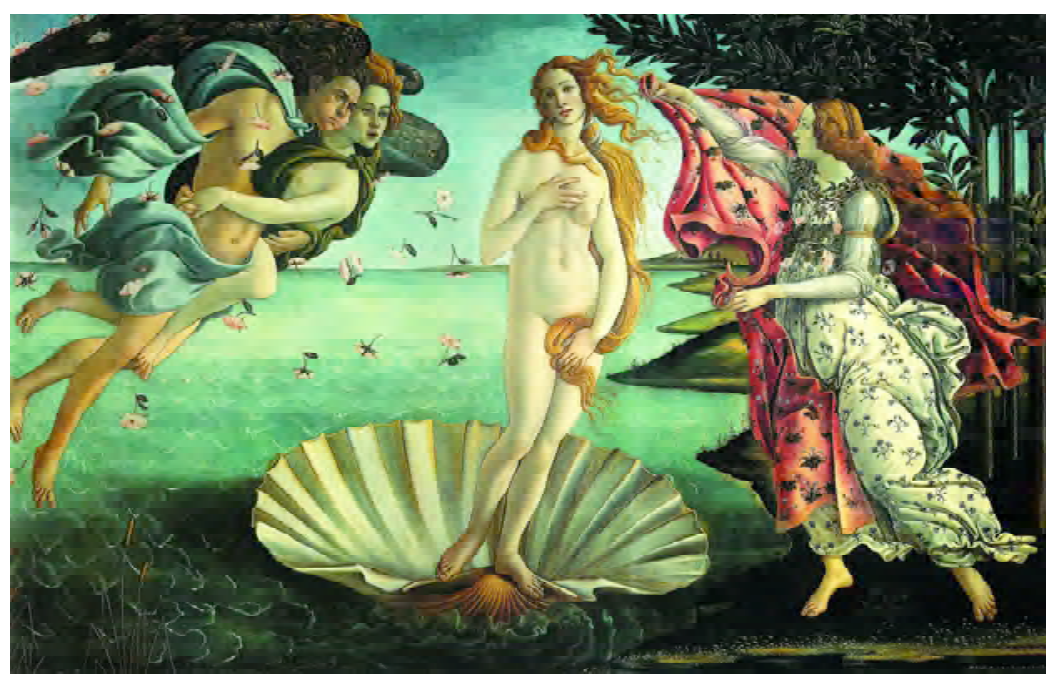

Resim:10

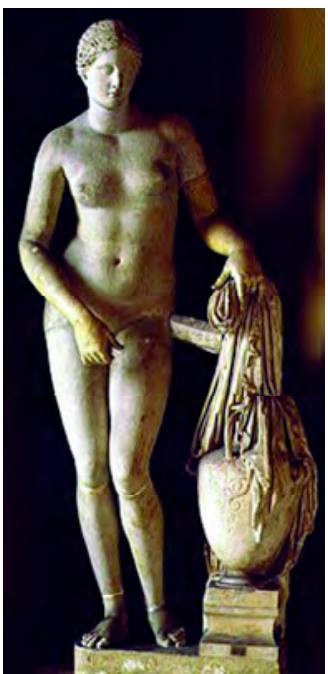

Resim:11 


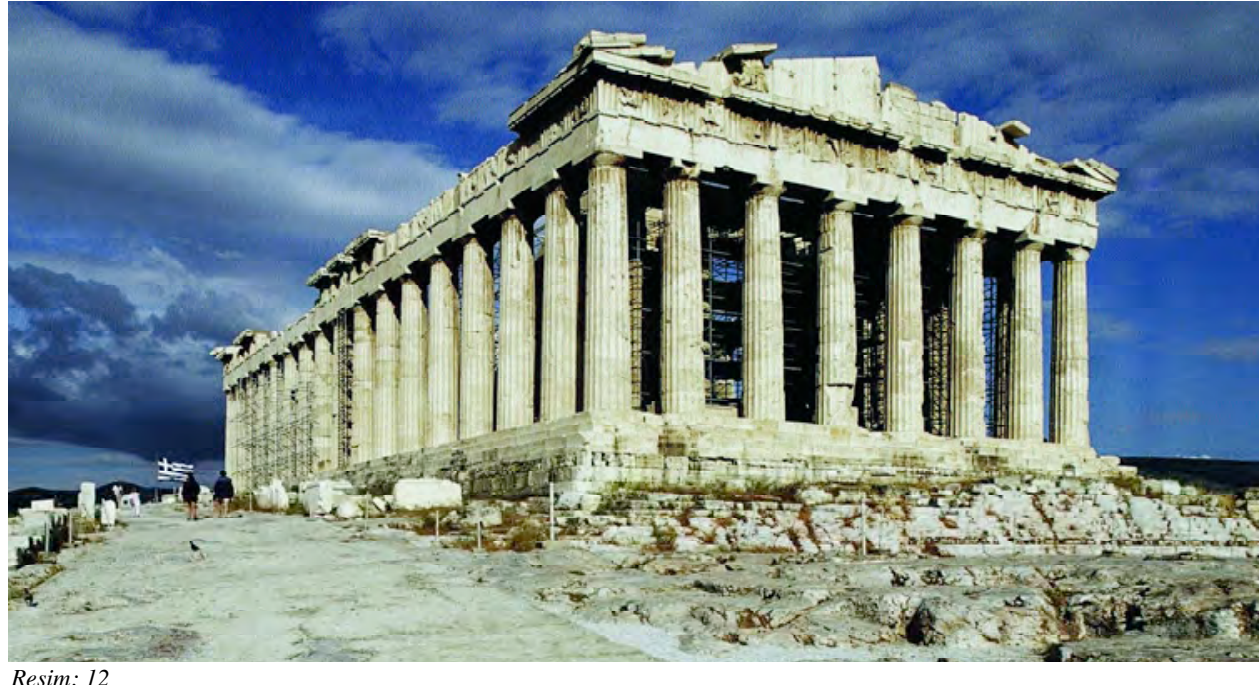

Günümüze ulaşabilmiş en önemli mimarlık ürünleri olarak, "peripteros" tipinde, "dorik", “iyonik" veya "korentiyen” tipi başlıklı kolonlar ve heykellerle rölyeflerin süslediği, üçgen pedimentli tapınaklardan söz edebiliriz. Örneğimiz, M.Ö. 5. yy.'dan kalma Atina Akropolü'ndeki Parthenon gibi (Resim 12) .

Sesler arasındaki aralıkların duygular, hatta sağlık üzerinde etkileri olduğunu gören Yunanlılar, "Dorien", "Frigien" gibi tek sesli makamlar oluşturmuşlar, "Lir", "Kithara", "Harp" gibi telli, “Aulos", "Salpinx” gibi nefesli sazlar geliştirmişlerdir. Burada 5. yy.'dan Euripides’in “Orestes Trajedisi”nden bir koro parçasını dinliyoruz: “Orestes Stassimo”.

Başlangıcı Truva'dan kaçan Eneas ile beraberindekilerin İtalya kıyılarına çıkmalarına dayandırılan Roma ise, Antik Yunan'ın aksine üç kıtaya yayılmış devâsa bir imparatorluktur.

Başlarda Etrüsk hâkimiyeti, M.Ö. 500’lerde Cumhuriyet, Cesar'ın öldürülüşünün ardından M.S. 27'de Augustus ile başlayan İmparatorluk dönemi, sürekli iç çatışmalar ve savaşlar, 1. yy.'da ortaya çıkan Hristiyanlığın, büyük işkencelere, toplu öldürümlere rağmen önlenemeyişi, M.S. 395'te Thedosius'un İmparatorluğu, “Batı”, “Doğu” olarak ikiye ayırması Roma tarihinin köşe taşları olarak kabul edilir. Bildiğimiz gibi, Batı Roma 476'da Ostrogotlar, Doğu Roma, yani Bizans 1453'te Osmanlılar tarafindan ortadan kaldırılmıştır.

Askerlik, mimarlık, mühendislik ve hukuk alanlarında çok ileri olan Roma, sanat alanında genellikle Antik Yunan sanatının etkisinde kalmıştır. Resim alanında öncelikle Pompeii villalarındaki freskleri ve Anadolu'da Zeugma ve diğer bazı yerlerdeki mozaikleri örnek gösterebiliriz. Ayrıca Roma hakimiyeti altındaki Mısır'da Fayyum'da bulunan mezar resimleri, portre türünün ilk örneklerinden sayılacak mükemmeliyettedir (Resim 13).

Heykelde ise imparatorların, önemli kişilerin, aile büyüklerinin gerçekçi bir yaklaşımla ele alındı ̆̆ 1 büstler ön plandadır.
Resim: 12

Parthenon, Atina

MÖ 447-438, Ictinos, Callicrates, Phidias.

Resim: 13

Fayyum Portre, Misir, MS 1-2. yy.

Resim: 14

Colosseum

Roma, MS 70-80

Resim: is

Venüs'ün Eros'u Cezalandırması

Pompeii duvar resmi, MS 70.

Resim: 16

Henry II'nin Kitabından

2. yy. başları.

Resim: 17

Marcus Aurelius

Roma, MS 2. yy.

Resim: 18

Sarlman (?)

MS 9. yy. baslar.

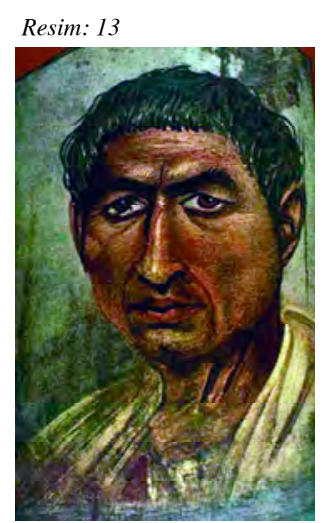

4 Sayı 18, 2014 


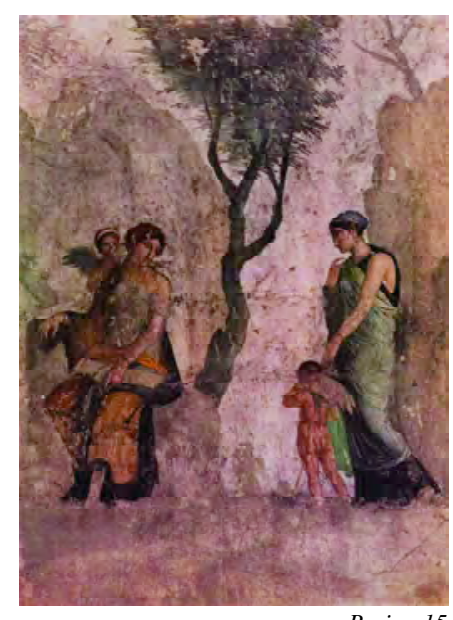

Resim: 15

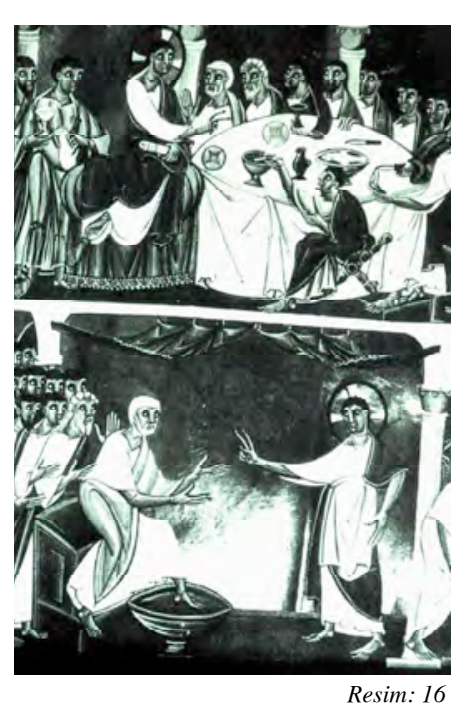

Mimarlık ve mühendislik alanında da günümüze ulaşmış 1. yy.'dan birkaç örnek olarak, Fransa'daki Pont du Gard'1, Roma'da Colosseum'u (Resim 14) ve Yunan etkisinin açıça görüldüğü girişi ve o dönem için inanılmaz açıklıkta, $42 \mathrm{~m}$. çapında kubbesiyle Pantheon'u gösterebiliriz. Bunda olduğu gibi diğer bazı Roma yapılarında, gene Yunan mimarisinden gelen üçgen alınlıkların görüldüğünü de belirtelim.

\section{Ortaçă}

Batı Roma İmparatorluğu'nun yıkılışı, Ortaçağın başlangıcı sayı1ır. Her alanda çağın en ileri gelişmiş devleti Roma'nın yerini, “Kavimler Göçü”nde Doğu'dan gelen ve bağımsız devlet kurma savaşları veren, Gotlar, Franklar, Germenler, Vandallar ve Anglosaksonlar almışsır. M.S. 7. yy.'da Müslümanlar'ın İspanya'ya çıkarak Endülüs Emevi Devleti'ni kurmaları da, dönemin en önemli olaylarından biridir.

8. yy.'da bir Germen kabilesi Karolenjlerden Şarlman'ın, Karolenj İmparatorluğu'nu kurmasına kadar geçen 400 yıllık süre genelde "Karanlk Dönem", onu izleyen "Ottolar dönemi" "Romanesk", 13. yy.'dan başlayarak, İngiltere ve Fransa'nın giderek güçlendiği, "100 Yll Savaşı”nın yaşandığı ve genellikle Bizans'ın yıkılışına kadar olan dönem ise “Gotik” olarak adlandırılmışıtır.

Resim: 17-18

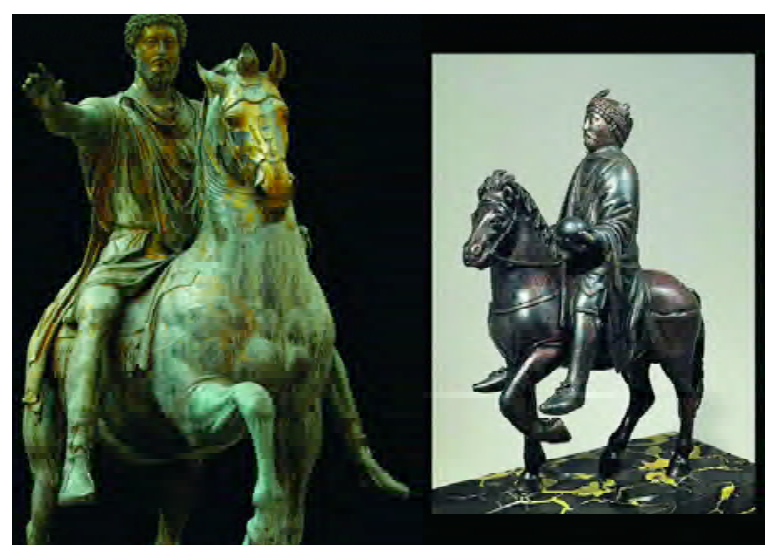

Büyük çalkantıların, dini bağnazlıkların, "skolastik düšünce" ile "feodalite"nin hâkim olduğu Avrupa'da sanatın gelişmesi değil, ancak gerilemesi beklenebilirdi. Bunun bir örneği olarak sırası ile, Pompeii'den bir Roma resmini, İsa ve Havarilerinin yer aldığ 1 Romanesk bir resim ile (Resim 15-16), Roma'dan İmparator Marcus Aurelius'un atlı heykelini de Ortaçağ'dan Şarlman'ın atlı heykeli ile karşılaştıralım ayrıntıdan bütüne (Resim 17-18), 600 yıl sonrasının sanatındaki gerileme açıça görülmüyor mu?

Resim sanatı ancak Gotik sonlarına doğru, 1300'lerde Giotto ile, heykel ise, Gotik katedrallerde yaygın olduğunu gördüğümüz, ince 


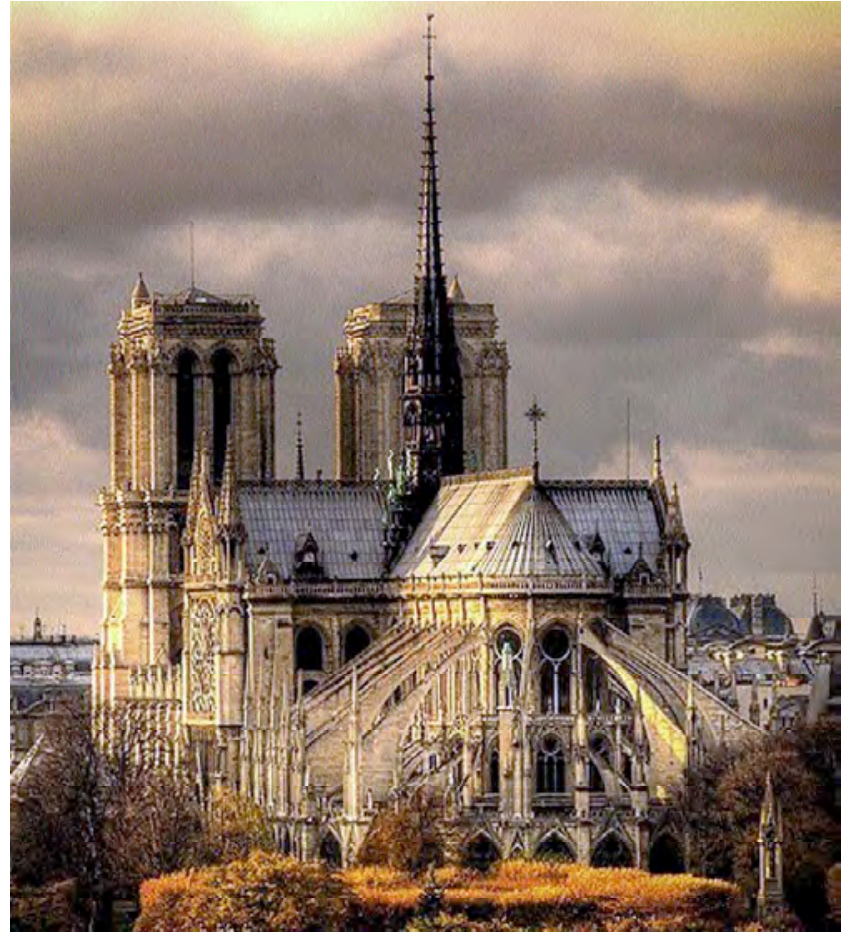

uzun silüetli, derin drapeli giysili dini figürleriyle ciddi bir gelişme gösterecektir.

Mimarlıkta kalın masif taş duvarlı küçük açıklıkların, Roma tarzı dairesel kemerli yapılarla geçildiği kilise ve manastırlar, hiçbir zaman Roma ile kiyaslanamaz. Bu konuda, Karolenjlerin Aachen Şapeli'ne kadar olumlu bir gelişme görülmeyecektir. Mimarlık alanındaki en önemli gelişme kuşkusuz, yapılarda kuvvetlerin düşeye yönlendirilmesi olmuş, bunun sonucunda sivri kemerleri, uçan payandaları, ağırlık kuleleri ve ince duvarları ile, örneğin burada gördüğümüz, Notre-Dame gibi ilk Katolik katedraller inşa edilmeye başlanmıştır (Resim 19).

Müziğe baktığımızda, günümüze ulaşabilen ilk örnekler tek sesli Hrıstiyan ilâhileridir. Papa Gregor I, müziği disipline etmeye yönelmiş, bu arada bazı melodiler ahlâka aykırı bulunarak elenmiş, uygun bulunanlara ise dinî güfteler giydirilmiştir. Müzikteki ilk özgün kıpırdama "trubadur" denen gezgin şair ve bestecilerle başlamıştır. Hayattan, aşktan, ölümden bahseden bu şarkıcıların arasında Richard I, Alfons X ve bir şarkısını burada dinlemekte olduğumuz Thibaut IV gibi krallar da bulunmaktadır. Dönemin müziğindeki en önemli gelişmeler olarak, Arezzo'nun notalamaya yönelik ilkel bir sistem bulmuş olması yanında dönem sonlarında çok sesliliğe doğru bir yönelişten söz edebiliriz.

Müslümanlığın Avrupa'daki varlığı ve 1071'de Selçukluların Anadolu'ya girişleri Ortaçă̆ Avrupa'sını son derecede endişelendirmişti. Avrupa'daki Müslüman varlığına son vermek için sürdürülmekte olan "Reconquista" hareketi hızlandırılırken Papa Urban II, Kudüs'ü kurtarmak bahanesiyle "Haçlı Seferleri"nin ilkini başlatıyor, Avrupa bu savaşlarda umduğunu bulamıyorsa da, o dönemde tıptan matematiğe, fiziğe, coğrafyaya ve felsefeye, kendisinin çok ilerisindeki "íslâm Uygarlığı”nı tanımış oluyordu. "Reconquista”da giderek başarıya ulaşmaktaysa da, Avrupa için Doğu'da yeni bir tehlike belirmişti:

Osmanlilar. 


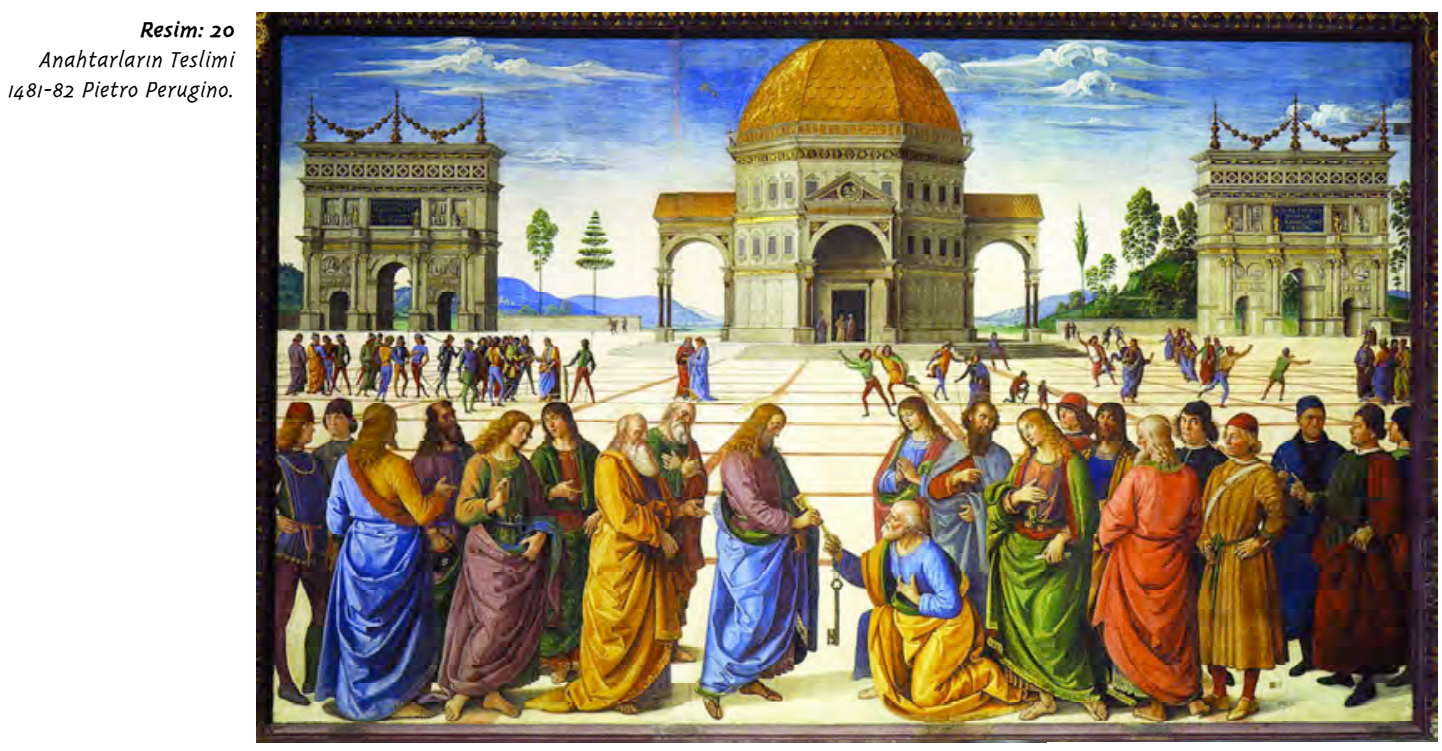

\section{Yeniçă}

\section{Rönesans}

Genel olarak Yeniçağın Rönesans ile başladığı ve 1789 “Fransız Devrimi”ne kadar sürdü̆ğ̈ kabul edilmiştir. Dilimizdeki karşılığı "yeniden doğuş" olan bu deyimde kastedilen, Antik Yunan ve Roma uygarlıklarına adeta yeniden kavuşulmasıdır. Kolomb'un Amerika'yı keşfi, Gütenberg'in matbaayı icâdı, Martin Luther' in getirdiği din reformu ve kanımca en önemlisi, Osmanlıların 1453'te, o zamanki adıyla Konstantinopl'u fethederek Bizans'a son vermesi Rönesans'1 getiren etkenler sayılır. Bizans'tan kaçan din ve bilim adamları ile sanatçılar sayesinde Avrupa Antik Yunan ve Roma'nın kültürel ve sanatsal birikimine

Resim: 21 St. George 1416, Donatello.

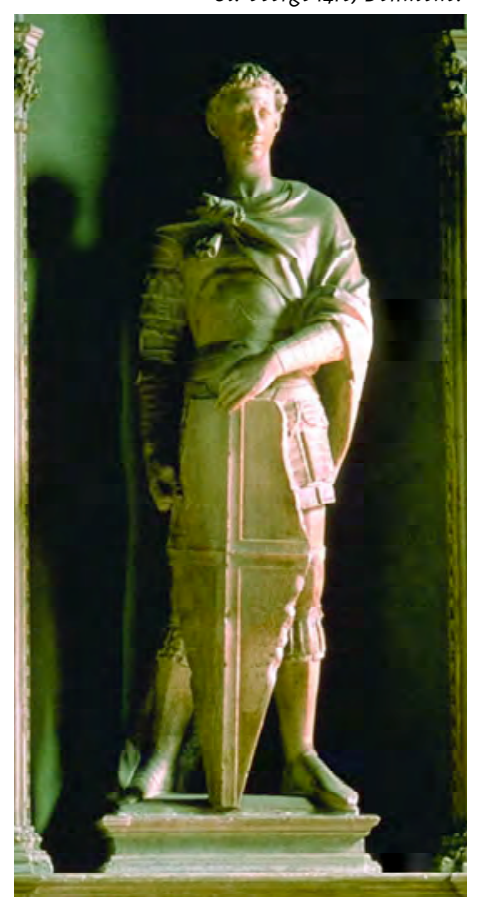
kavuşabilmiş, Ortaçağa hâkim olan, tamamen dine dayalı "Skolastik Felsefe" önemini yitirmiş, insan ve doğa gerçeklerine yönelinmiștir. Rönesans'ın beşiği olarak gösterilen İtalya'da, özellikle ticaret yoluyla gittikçe zenginleşen Floransa, Rönesans'ın öncülüğünü yapmıştır.

Rönesans'ın sanatına baktığımızda, hemen bütün dallardaki ortak yaklaşım doğallık, sadelik ve dengedir. Ortaçağda dini konuların tek konu olmasının aksine, Rönesans'ta dini konuların yanı sıra Leonardo da Vinci, Rafael, Tiziano gibi sanatçılarla portre sanatının, adeta fotografik mükemmelliyetteki örnekleri ortaya çıkmaya başlamıştır. Perugino'nun 1400'lerin başına ait "Anahtarların Teslimi” adlı freskine baktığımızda Rönesans resminin tüm özelliklerini görüyoruz: Simetrik kompozisyon, duraganlık, ön plândan geriye açıkseçik görünürlük, sadelik (Resim 20). Ayrıca geri plandaki yapılarda Yunan ve Roma'dan birer motif olarak alınmış üçgen alınlıklarla tam dairesel kemerler Rönesans'ta çok kullanılmış yapı motifleridir.

Ghiberti, Nanni de Banco, Donatello gibi erken dönem heykeltraşları ile başlayan Rönesans heykelinde de, statik bir anlayış yanında, figürlerde titiz bir yaklaşım, doğallık, gerçekçilik yansır (Resim 21). İleriki yıllarda ise, aynı zamanda iyi bir ressam ve mimar olan Michelangelo'nun “ölen Esir" ve benzeri çalışmalarında harekete yer vermesi, “Maniyerizm”e bir yöneliş olarak yorumlanacaktır. 


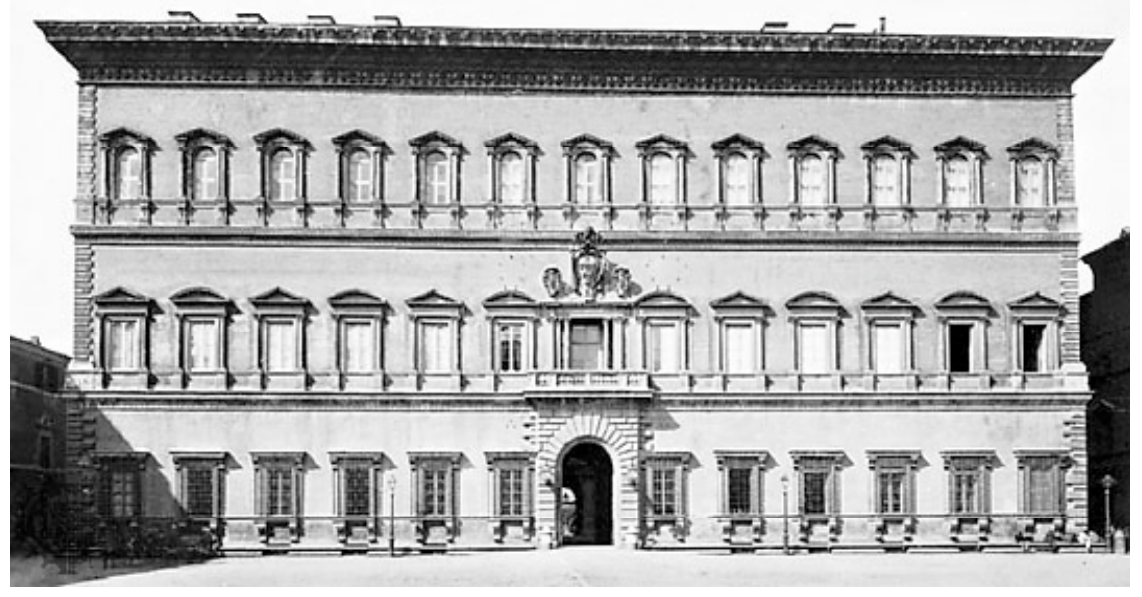

Resim: 22

Rönesans mimarisine baktığımızda da, Antik Yunan ve Roma mimarisinden gelen, pencere ve kapı üstlerinde üçgen alınlıklar ve tam dairesel kemerler görüldügüune değinmiştim. Genelde kitle mimarisi ile iç mekânlarda dik açılı bir geometrinin hâkim olduğu yapılarda, örneğin Sangallo'nun "Palazzo Farnese” adlı yapısının cephesinde de görülen bu motiflerin dışında, diğer türde süslemelere yer verilmemiştir (Resim 22).

Müzik alanında Batı müziğinin temelini oluşturacak önemli gelişmelerin başlangıcı da Rönesanstır. Geçmiş dönem sonunda başlamış olan iki sesli müzik, giderek gerçek bir polifonik karakter kazanmıştır. Armoni, kontrpuan, mevcut sazların yanında, ses imkânları daha yüksek nefesli sazlar ile daha büyük boyutlu dinî eserlere ek olarak, giderek yaygınlaşan dünyevî eserler Rönesans müziğini oluşturmuştur. Rönesans müziği diğer dallarda olduğu gibi sade ve duragandır. Dönemin bestecileri olarak Dufay, Dunstable, Desprez, Palestrina ve Gabrieli gibi adları sayabiliriz.

Burada bir parantez açarak Rönesans müziği ve resmi ile dönemin güçlenen devleti Osmanlılardaki müzik ve resmi karşılaştıralım. Önce erken Rönesans bestecilerinden Dufay’dan, belirgin çok seslilik yanında nefesli sazların dikkat çektiği duragan bir beste. Konstantinopl'un kaybedilişinin Avrupa'da yarattığı üzüntüler ve pişmanlıkların dile getirildiği, "Lamentatio sanctae matris eclestiae”. Bunu, yaklaşık dönemde Osmanlı sarayında da bulunmuş Merâgalı Abdülkadir'in “Rast Kâr-ı Muhteşem”i ile karşılaştıralım. Diğerinin çok sesliliğine karşılık tek sesli olan bu eserde melodi ve ritmin daha önemsendiği açıkça görülmüyor mu? Hemen belirtelim, Osmanlıların yaşam biçimlerine, inanışlarına daha uygun bulunduğu için, tek seslilik terk edilmeyecek, hiçbir zaman çok sesliliğe geçilmeyecektir.

İkinci karşılaştırma Tiziano'nun yaşlılık döneminden bir otoportresi ile Barbaros Hayrettin'in bir minyatürü. İlkindeki adeta fotografik yaklaşıma karşılık, Barbaros'da hacimsiz, derinliksiz bir resimle karşılaşıyoruz (Resim 23-24). Müzikte olduğu gibi, bu gene Osmanlıların yukarıda değinilen yaklaşımından kaynaklanmakta olup, Osmanlı minyatürden vazgeçmeyecek, resimde de perspektife yer vermeyecek, heykel ise hiçbir zaman söz konusu olmayacaktır.
Resim: 22

Palazzo Farnese

1541-1580

Antonio de sangallo (Genç) Michelangelo.
Resim: 23 Barbaros Hayreddin 1545 (?), Nakkaş Nigâri. Resim: 24 Otoportre 1567, Tiziano Vecellio.

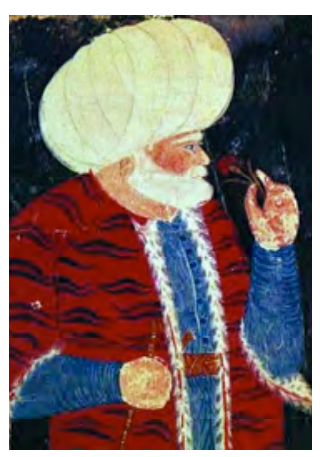

Resim: 23

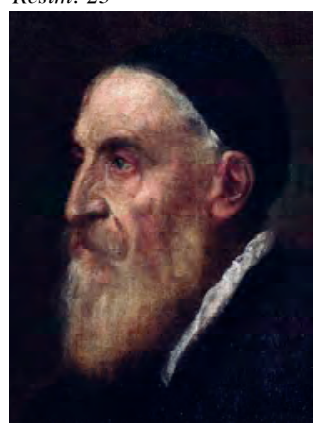

Resim: 24 

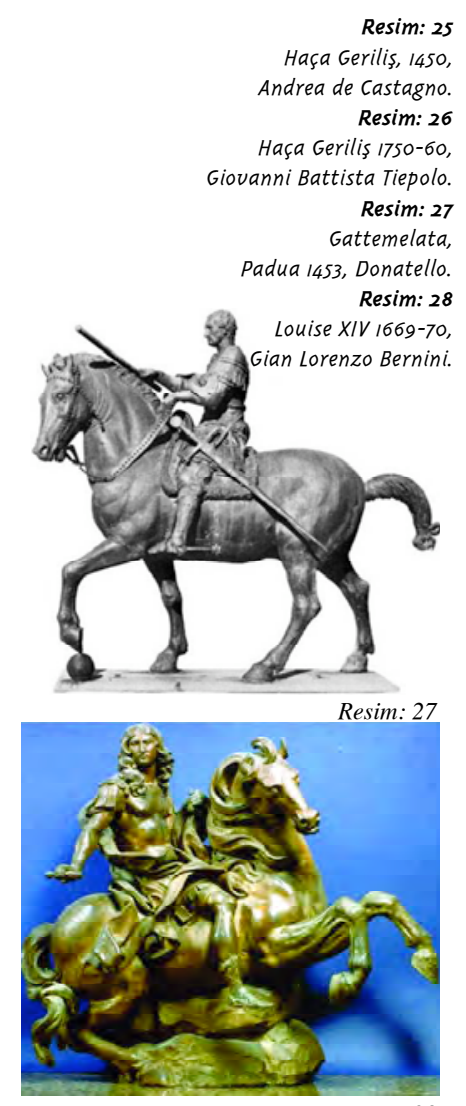

Resim: 28

Resim: 29

Segrestia Vecchia (Kutsal Hazine)

1421-40, Filippo Brunelleschi.

Resim: 30

Ottobeuren Manastir Kilisesi 1748-55, Johann Michael Fischer.
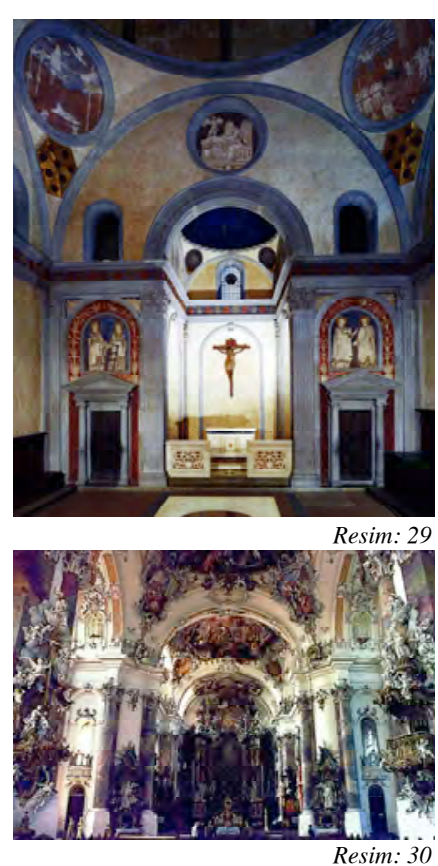

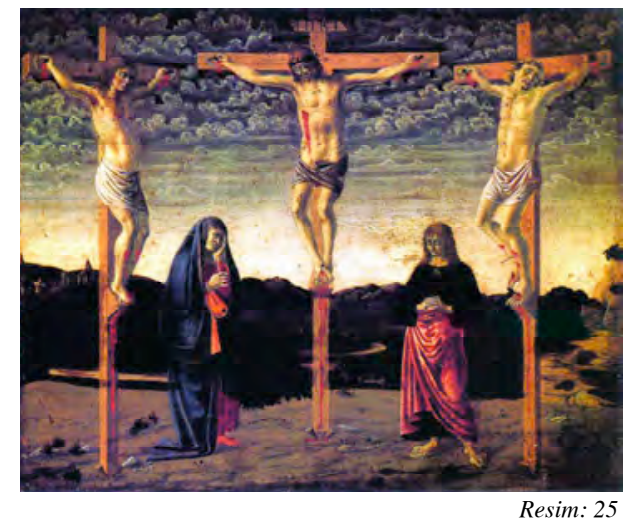

Barok

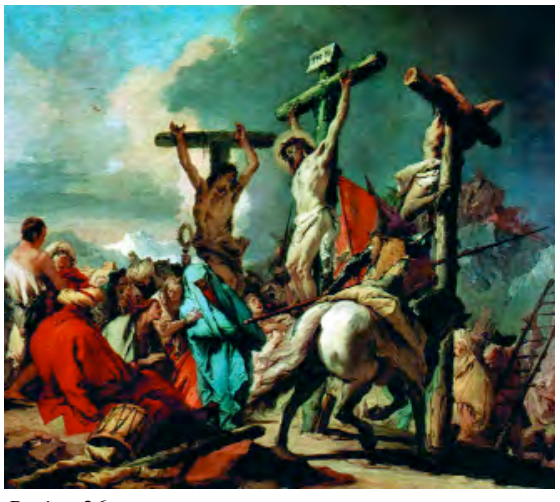

Resim: 26

Rönesansın gösterişten uzak, sade, dengeli, duragan yaklaşımına karşıt bir gelişme sonucu, 17. yy. başlarında "Barok" olarak adlandırılan yeni bir dönemle karşılaşıyoruz. Bu dönem hemen hemen 18. yy. sonlarına, 1789 “Fransiz Devrimi”ne kadar etkisini sürdürecektir.

16. yy. sonlarına doğru resim ve heykel sanatlarında Rönesans disiplininde bir sapma görülür. Michelangelo ile heykele dinamik bir ifade ve hareket gelir, Tiziano ve Tintoretto'nun resimlerinde, kompozisyonun genelinde hareketlilik yansırken açık-seçik görünürlük yerini kısmî belirsizliklere bırakır. "Maniyerizm” olarak adlandırılan bu gelişme, Barok sanatın başlamasındaki işaretlerden biridir. Baroğun tüm sanat dallarındaki ortak yaklaşım, abartı, hareket, yoğun bir süsleme, bir renk zenginliği ve duraganlığa karşı dinamizm olarak özetlenebilir.

Rönesans ile Barok karşıtlığına resim, heykel ve mimarlıktan örneklerle bakalım: Önce Rönesans'tan Andrea de Castagno ile Barok'tan Tiepolo'nun İsa'nın haça gerilmesi konulu iki resim (Resim 25-26). Sonra iki atlı heykel, Donatello'dan Gattemelata, Bernini'den de Louise XIV (Resim 27-28) ve sonuncusu, mimarlıktan, Brunelleschi'nin San Lorenzo'daki “Segrestia Vecchia”sı ile Avusturya'da Geç Barok Ottobeuren Kilisesi'nden birer enterior (Resim 29-30). Hepsinde Rönesans ve Barok sanat hakkında belirttiğimiz tüm özellikler açıkça görülmüyor mu?

Barok resmin önemli özelliklerinden biri de Caravaggio ile başlayan 1şık-gölge kontrastıdır. Bir noktadan ışık alan resimleriyle George de la Tour, zengin, renkli, hareketli resimleriyle Rubens, portreleriyle Rembrant, yeni yayılmaya başlayan "peyzaj”larıyla Ruisdael, günlük hayattan sahneler ve o dönemde ortaya çıkan "natürmort"larıyla Chardin, dekoratif freskleriyle Tiepolo Barok resmin önemli temsilcileridir.

Müzikte de, diğer dallarda yansıyan özellikler yanında tonalitenin, ritmin önem kazandığı, çok sesli, dinamik, kontrastlı bir yapı hâkimdir. İtalya'da Corelli, Vivaldi; Almanya'da Bach, Telemann; İngiltere'de Händel Barok müziğin akla gelecek ilk isimleridir. Klavsen, şimdiki şekillerini almış yaylı, nefesli gibi aletler, sonat, konçerto gibi formların yanı sıra oratoryolar, giderek operalar Barok müziğin gelişimini yansıtır. Şimdi burada Rönesans ve Barok’tan iki örneği karşılaştıralım: Attaignant'ın yayımladı̆̆ ${ }_{1}$ anonim bir "pavan” ile 
D. Scarlatti'den bir “sonat”. Buradaki müzikal ifade farkına ve spinetin yanında, gelişmiş bir türü olan klavsenin ses gücüne ve zenginliğine de dikkat edelim.

Osmanlı'da durum nedir? Avrupa gittikçe güçlenmekte, Osmanlı'da ise "Lâle Devri"ni de kapsayan “Gerileme Dönemi” yaşanmaktadır. Nakkaş Levnî’nin, geleneksel minyatürler verdiği bu dönemde, “Ahmet III çeşmesi”, III. Osman’ın yaptırdı̆̆ı “Nûr-u Osmaniye”, ardından III. Selim'in Üsküdar'daki "Selimiye Camisi” gibi örnekler Barok mimarinin Osmanlılarca resmî şekilde kabul edildiğini göstermektedir.

18. yy.'ın son yarısında iki olay, buhar gücünün kullanılması ve çeliğin kitlesel olarak üretilmesiyle başlayan "Endüstri Devrimi" ve 1789 "Fransız Devrimi” Baroğun olduğu gibi Yeniçă̆ın da sonunu belirlemiştir.

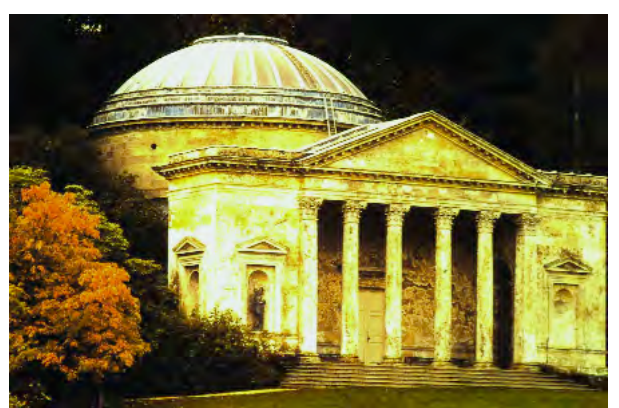

Resim: $31-32$

\section{Yakınçă}

Az önce belirttiğim gelişmelerle başlayan Yakınçă̆, daha başlarda, Avrupa'da, hızlı bir endüstrileşme, onu izleyen büyük bir üretim, demokrasi anlayışının yayılışı, "aydınlanma felsefesi"nin çağın düşünsel, sanatsal ortamının oluşumuna katkısı gibi olumlu gelişmelerle başlamasına rağmen ne yazık ki büyük savaşların, kıyımların yaşandı̆̆ olmuştur.

Dönem başlarında Barok ile onun daha ince, iç ve dış bükey eğrilikli, aşırı süslü devamı olan Rokoko’ya karşı oluşan bir tepki, sanatta Antik Yunan'a ve Roma’ya yeni bir yönelişi getirmiştir. "Neoklasizm” olarak adlandırılan bu eğilimde, yapılarda Antik Yunan tapınakların pedimentlerini hatırlatan üçgen motifler, dorik veya iyonik kolonlar görülmeye başlanmıştır. Resimde Louis David'in Roma konulu resimleri, Canova'nın heykel ve mimarlık çalışmaları bu akımın en önemli örnekleri olarak gösterilebilir. Bir örnek olarak Canova'nın 1819 tarihli “Tempio Canoviano”sunu, 2. yy. başlarının Roma Pantheon'u ile karşılaştıralım (Resim 31-32). Arkasından da gene onun, "Utkulu Venüs” diye adlandırılan, Napoleon'un kız kardeşi Kontes Paoline Borghese'nin heykeliyle, Hellenistik dönemden “Melos Venüs”ü (Resim 33-34). Burada görünen Neo Klasik yaklaşım hiçbir zaman ileriye yönelik bir aşama olarak kabul görmeyecektir. Ayrıca dönem boyunca "Neo Gotik", "Neo Rönesans", "Neo Barok" gibi gene geriyi işaret eden eğilimler de görülecektir sanatın her dalında.

Gluck'un operalarında, Alceste'de, Iphigenia konulu iki operasında veya Haydn ve Mozart ile klasik müzik döneminin en önemli bestecilerinden Beethoven'ın Prometheus

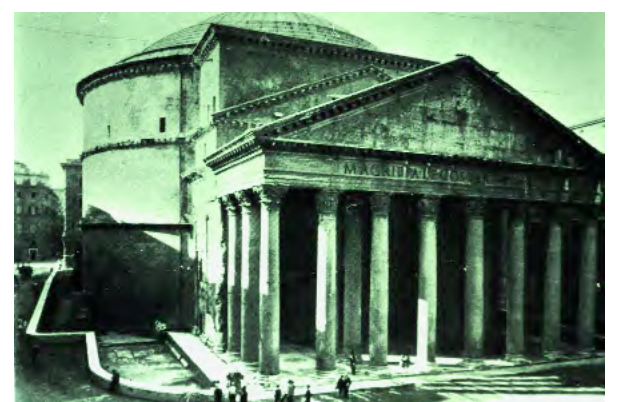

Tempio Canoviano, Treviso 1830, Antonio Canova.

Resim: 32

Pantheon, Roma

MS $118-128$, şamlı Apollodorus.

Resim: 33

Venüs Victrix (Utkulu Venüs)

1805-08, Antonio Canova.

Resim: 34

Melos Venüsü.

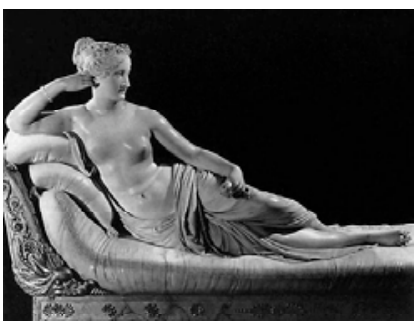

Resim: 33

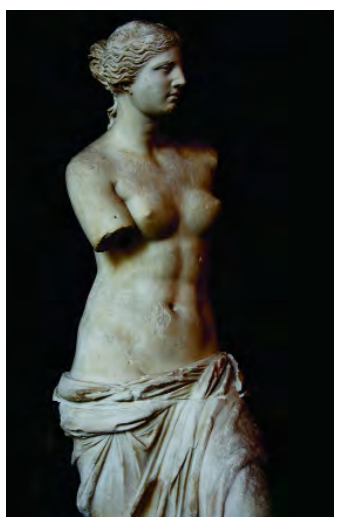

Resim: 34

10 sayı 18, 2014 

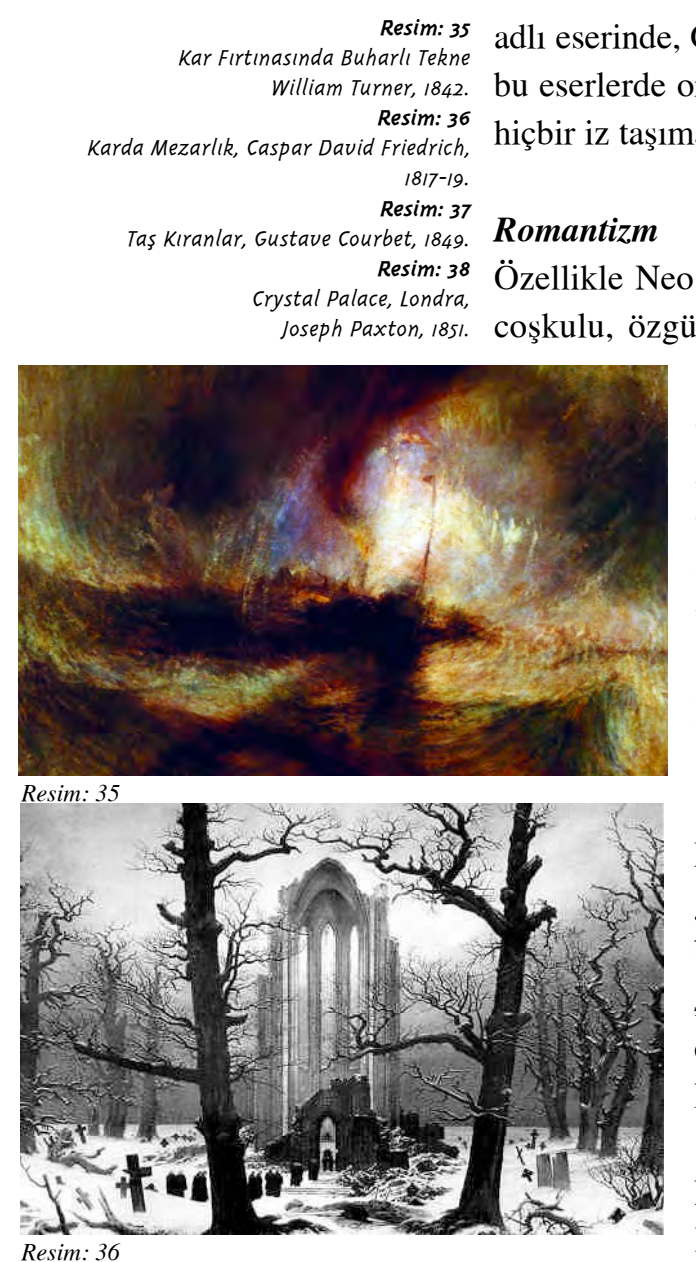

Resim: 36

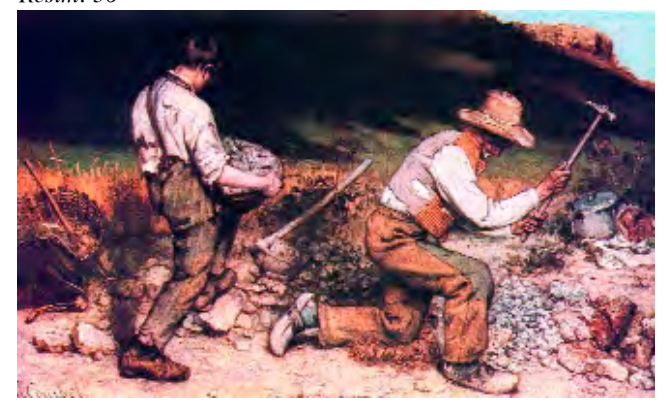

Resim: 37

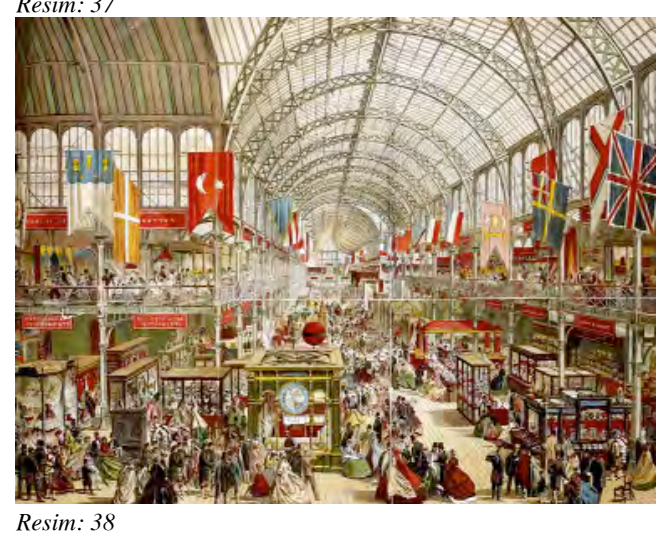
olması sonunda "Romantisizm" akımı ortaya çıkmıştır. Özellikle edebiyatta çok yaygın olan bu akımın resim alanında, İngiltere'de William Turner, Almanya'da Caspar David Friedrich ve Arnold Böcklin, Fransa'da Gericoault gibi sanatçılardan söz edebiliriz. Turner'ın “Kar Fırtınası” adlı eserine baktığımızda, doğayla çatışma, Caspar David'in resimlerinde de yoğun ve acı bir duygusallık yansıdığı görülür (Resim 35-36). Hemen hemen aynı yıllarda, burada "Taş Kıranlar" adlı tablosunu gördüğümüz Courbet ile Millet yeni bir akımın temsilcileri olarak ortaya çıkıyorlardı: "Realizm" akımının (Resim 37).

Müziğin klasik döneminin bestecileri Haydn, Mozart ve Beethoven ile gelişen sonat, konçerto, senfoni bu dönemde daha yeni sazların da katıldığ büyük orkestralarla çalınmaya başlanmış, opera gelişmiş, ayrıca "senfonik şiir", "lied” (şarkı) gibi yeni formlara yönelinmiştir. Dönemin bestecileri olarak Schubert, Mendelssohn, Liszt, Chopin, Schumann, Brahms ve Berlioz'u hatırlayabiliriz.

Bu yıllar "Endüstri Devrimi”nin endüstriyel ürünlerine pazar bulma amaciyla Dünya sergilerinin, fuarların açılmaya başladığı yıllardır. Bunların öncüsü olan 1851 Londra Dünya Sergisi’nde, ilk defa malzeme ve yapım teknolojisi açısından, çağın yapı geleneklerine hiç uymayan bir yapı gerçekleştiriliyordu, tasarımını Paxton'un yaptığ Yapı tamamen dökme demir ve camdan oluşuyor, dönem için inanılmaz açıklıklara ve alana sahip olan binanın yapımı bir yılı geçmiyordu (Resim 38). Bu yapı standardizasyon ve prefabrikasyonun ilk örneği olarak, ileride modern mimarlığın başlatıcısı sayılacak, onu 1889 Paris sergisinin "Eiffel Kulesi” izleyecekti. Ancak bütün bu çağdaş atılımların yanında, örneğin "Votiv Kirche" gibi geriye dönük mimari uygulamalar görülmeye devam ediyordu. Bir suikastten kurtulan Avusturya-Macaristan İmparatoru Franz Joseph'in şükran duyguları ile, tamamen "Neo Gotik" tarzda Viyana'da yaptırdığı kilisenin 1856'da başlayan yapımı 1879'a kadar 23 yıl sürecek ve bu yapı sanat tarihi kitaplarında hiçbir zaman övücü sözcüklerle anılmayacaktı. Oysa yapımına ondan beş yıl önce başlanmış olan "Crystal Palace" sadece bir yılda tamamlanmıştı ve tüm sanat tarihi kitaplarında saygın bir yere sahip olacaktı.

İster istemez burada bir parantez daha açmam gerekiyor sevgili öğrenciler: Ne yazık ki, benzer eklektisist gelişmeler bizde de görüldü, hem de aynı 
y1llarda. "Dolmabahçe Sarayı, Küçüksu Kasrı" gibi neo-barok, "Hamidiye Camisi” gibi neo-gotik, "Nusretiye Camisi” gibi ampir etkide binalar yapıldı. Sadece Osmanlı'da değil, benzer davranışa Cumhuriyet döneminde de yer verdik. "Sultanahmet" ve "Selimiye"nin kopyaları sayılabilecek, Ankara'da "Kocatepe" ve Adana'da "Sabancı Merkez" camileri gibi. Vedat Dalokay'ın, başlamış inşaatı durdurulan "Kocatepe Camisi" yerine "Sultanahmet"in kaba bir replikasından ileri gidemeyecek olan, işçilik ve süsleme bakımından onun zerafetinden uzak Kocatepe'yi yaptık. Oysa Dalokay'ın uluslararası bir yarışmada birincilik kazanan ilk projesinin bir versiyonu, Pakistan'da "Kral Faysal Camisi" olarak inşa edildi. Bugün dünyanın en büyük camilerinden biri olarak ışıldıyor. Merak ediyorum, taştan başka hiçbir güvenilir malzemenin bulunmadığı Endüstri Devrimi’nin öncesinde, sürekli bölünmemiş cami mekânları yaratma çabası içinde olan Sinan, günümüzün yapı malzemeleri ile teknolojisini, yüzlerce metre açıklıklı "jeodezik kubbe"lerini görse neler yapmazdı? Düşünelim, biz bugün hâlâ atlı savaş arabalarıyla mı savaşıyoruz, bindiğimiz uçaklar Wright kardeşlerinkine benziyor mu?

Gene 1800'lerin Osmanlı Devleti'ne dönelim: Osmanlı Devleti artık “Dă̆ılma ve Yıkılış Devri”ni yaşamakta. 1839'da “Tanzimat Fermanı" ilân ediliyor. Yüz yıl önce "Pasarof̧̧a Antlaşması” ile Batı'nın üstünlüğüne boyun eğmeyi kabul etmiş olan Osmanlı, askeri alanda, dönemin deyimiyle "sslahat" projeleri için yabancı uzmanlar getiriyor. Mimarlık alanında, az önce değindiğimiz Osmanlı yapılarını o dönemin eğiliminin günümüze ulaşan simgeleri olarak kabul edebiliriz, bir kere daha değinmeyelim.

En göze çarpan gelişmelerden biri müzikte yaşanıyor: Kapatılan "Mehterhane-i Hümayun" yerine Batılı yapıda "Mızıka-yı Hümayun" kuruluyor, başına sonradan kendilerine "Paşa" rütbesi verilecek olan Giuseppe Donizetti ile Callisto Guatelli getiriliyor. Batılı anlamda marşların bestelendiği bu dönemde, sevimli ilginç bir şey de, Avrupa ülkelerine ilk ve son kez giden Padişah Abdülâziz’in burada dinleyeceğimiz, Batı tarzında "Valse Davet" adlı bir besteyi yapmış olması.

Resimde ise, Fransa'da resim öğrenimi gören Osman Hamdi Bey ve Abdülâziz tarafından Paris'e gönderilen, ilerideki adı ve rütbesiyle Şeker Ahmet Paşa ile Osmanlılarda Batılı anlamda resim başlamış oluyor, 1882'de Sanayi-i Nefise kuruluyordu. Burada gördüğümüz son Halife, Şehzade Abdülmecit Efendi'nin “Sarayda Beethoven” adlı tablosu (Resim 39) ve tablodaki kişilerin kıyafetleri de Batılı resim anlayışının yanında Batı hayat tarzının da Saray'da ne ölçüde kabul gördüğünün bir işareti.

\section{Empresyonizm}

Avrupa'ya dönelim: İlginçtir, yaklaşık 150'şer yıl süren Rönesans ve Barok dönemlerinin aksine daha kısa ömürlü, hatta biri bitmeden diğeri başlayan akımlar görülüyor. 1872'de Paris'te Monet ve arkadaşları, Manet, Pissarro, Sisley, Renoir, Degas yeni bir akımın başlatıcısı oluyorlar, genellikle dış mekânlarda, günün farklı saatlerinde doğa konularının, ayrıntılara girmeden anlık izlenimlerinin yansıdığı resimlerle "Empresyonizm”, bizdeki adıyla "İzlenimcilik" akımının. Örnek Monet'den "Impression de Soleil"

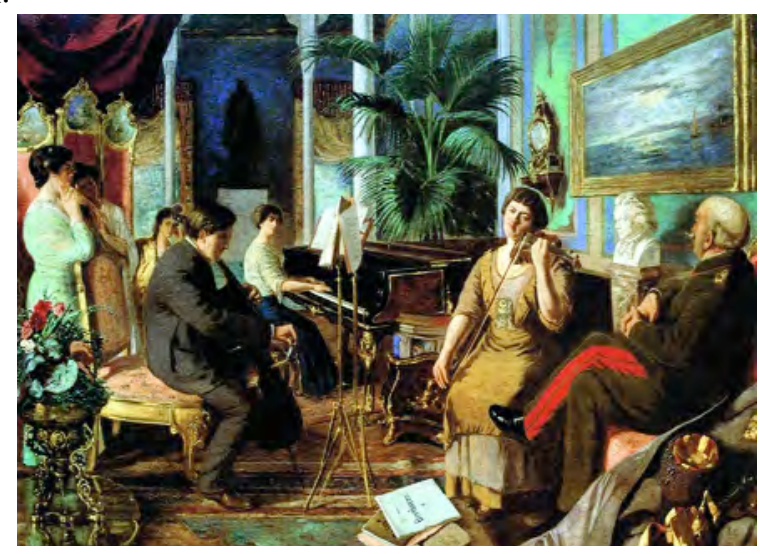

12 Sayı 18, 2014 

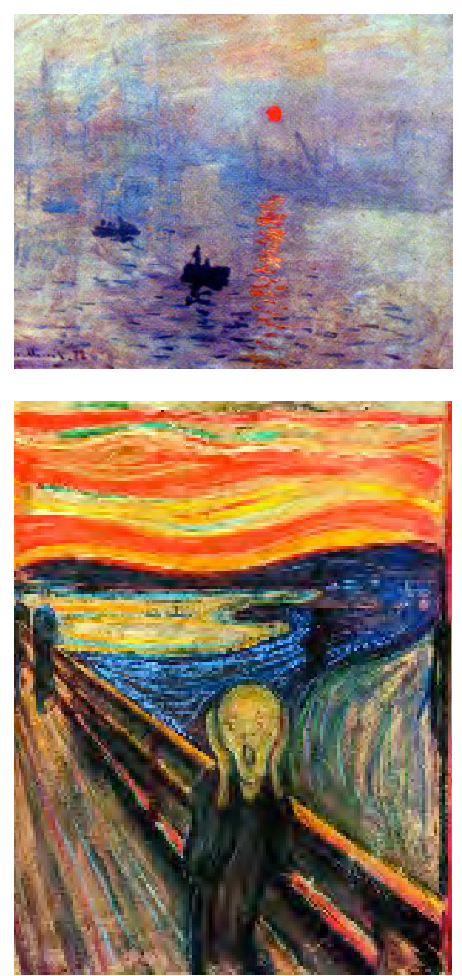

Resim: 40 Gün Doğumunun Izlenimi Claude Monet, 1874. Resim: 41 Skrik ( $(\zeta / g ̆ l k)$, Edvard Munch, 1893. Resim: 42 Casa Battlo, Barselona Antonio Gaudi, 1904.

Resim: 42

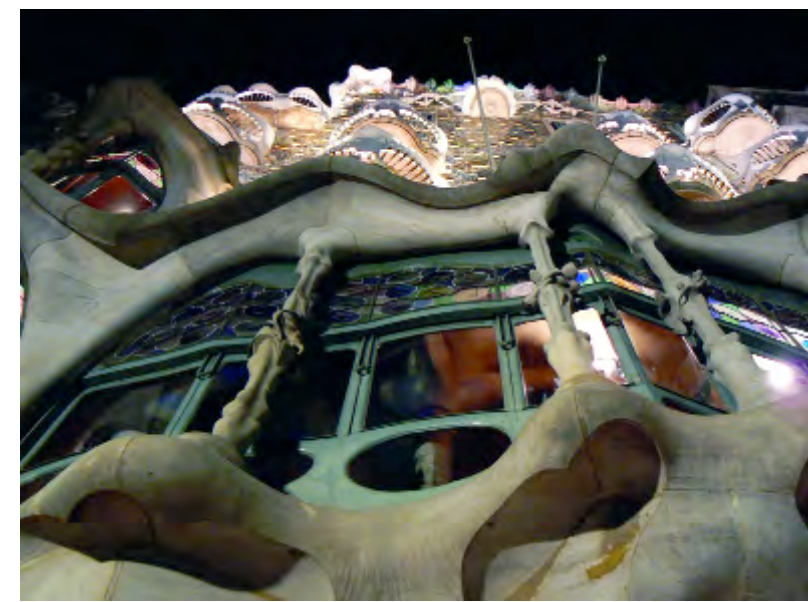

Böylece 20. yy.'a da gelmiş bulunuyoruz. 1. Dünya Savaşı, Osmanlı ile Avusturya -Macaristan İmparatorlukları'nın, Rus Çarlığı'nın yıkılmaları ve Sovyet devrimi gibi olayların yansıdığı ilk çeyrekte bu hızlı değişimlere uygun bir şekilde, gene çok yakın aralıklarla, ardı ardına gelen, hatta aynı zamanlı akımlar ortaya çıkıyordu.

Kübizm-F ütürizm

“Kübizm” 1900'lerin hemen başında Braque ve Picasso’nun, Cezanne’dan yola çıkarak, obje yüzeylerinin Picasso'nun örneğindeki gibi (Resim 43) "küpsel” parçacıklara ayrıldı̆̆ı resimler ile başlıyordu. Paris’teki genelde statik görünümlü bu akıma karşılık, Roma’da, ortak yönleri bulunan, ancak harekete yer verilen bir başka akım "Fütürizm” (gelecekçilik) ortaya çıkıyordu. Boccioni’nin resimlerinde, heykellerinde görebileceğimiz (Resim 44) bu akımın diğer sanatçıları olarak Giacomo Balla ve Carlo Carra’yı sayabiliriz.

Mimarlık alanında bir isme değinmek istiyorum. 1912-1914 yılları arasında "La Citta Nuova" (Yeni Şehir) adıyla, geleceğin şehrine ait taslaklar yapan ve 1916'da savaşta şehit düşen 


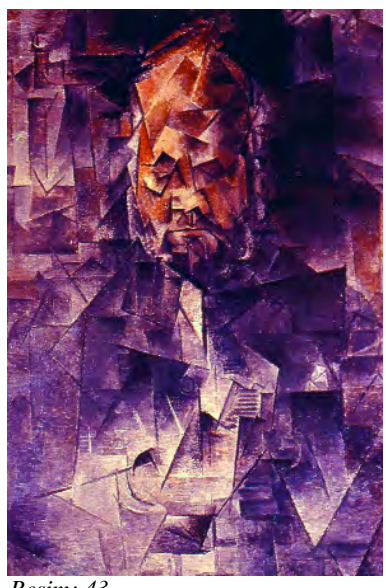

Resim: 43

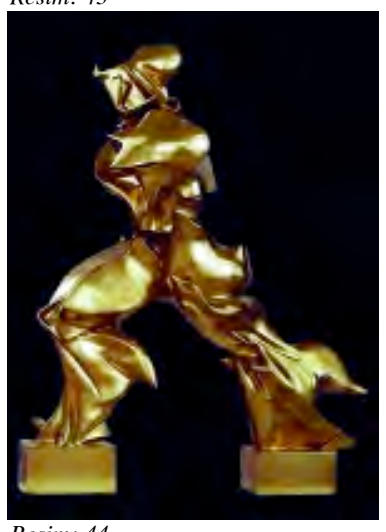

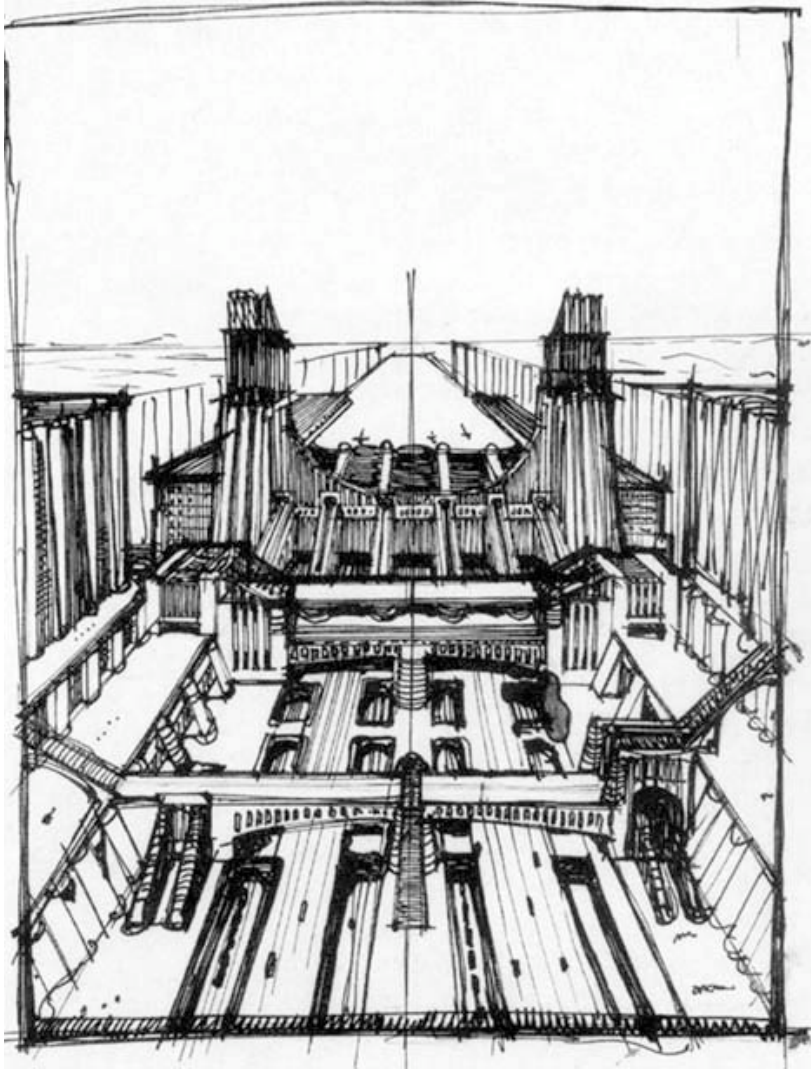

Resim: 45

Antonio Sant'Elia. Burada gördüğümüz çalışmasında (Resim 45), otomobilin daha emeklediği günlerde, trafiğin bir gün nasıl gelişmeler getireceğini, mimarinin nereye varacağını görmüş olması hayranlık ve saygı uyandırmıyor mu?

\section{Dadaizm}

O yılların en çarpıcı akımlarından biri de "sanat karşıtı" olarak da nitelendirilecek olan "Dadaizm”dir. Bu akım sürmekte olan 1. Dünya Savaşı’nın yaşanan felaketlerine, buhranlarına, bazı sanatçıların savaştan sorumlu tuttukları kapitalist burjuvalara karşı ortaya koydukları bir protesto özelliği taşır. Burada bir çalışmasını izlediğimiz Raul Hausmann (Resim 46) ve bir pisuvarı "Çeşme" adıyla sergileyen Marcel Duchamp, toplumun kabul edilmiş sanat eseri anlayışına aykırı eserler vermiş, sanata "ready made” (yapılmış, hazır), "kolaj”, “asamblaj” gibi çalışma türleri getirmişlerdir.

Müzikte Eric Satie, Cocteau'nun, dekorlarını Picasso'nun yaptığı, "Parade” oyununa, içinde rulet, tabanca, daktilo sesleri ile polis düdüklerinin duyulduğu aynı isimli bestesini yapmıştır. Burada dinlemekte olduğumuz “Balet Mechanique”te ise George Antheil'in uçak motoru sesine de yer verdiğini duyuyoruz.

\section{Soyuta Yönelme}

20. yy.'ın ilk çeyreğinde resimde beliren bir eğilim de, figürden uzaklaşarak soyut formlara yönelmektir. Kandinsky serbest formda renk lekeleri ile çalışırken, 1915'te Malevich

Resim: 43

Ambroise Voillard, Pablo Picasso 1910.

Resim: 44

Mekânda Tekil Formların Sürekliliği Umberto Boccioni

1913.

Resim: 45

La Citta Nouva, Antonio Sant'Elia

$1912-14$.

Resim: 46

Mekanik Kafa, Raoul Hausmann

1918.

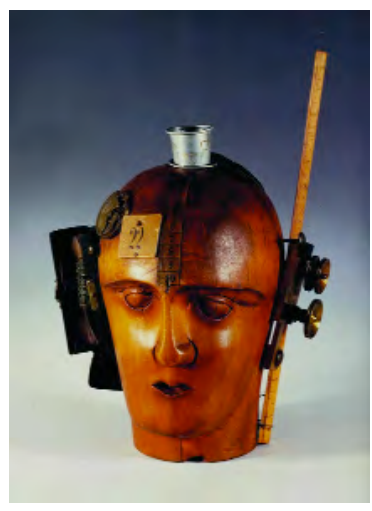

Resim: 46 


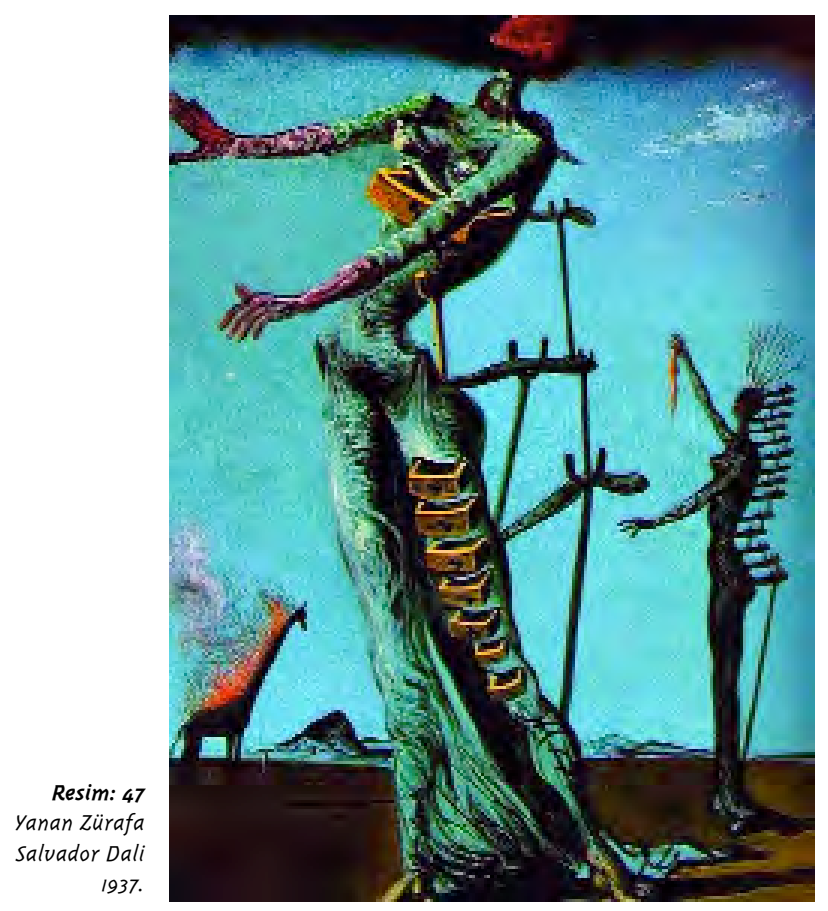

"Süprematist" olarak nitelendirdiği tek renkli kareler yapıyordu, "Siyah Kare", "Beyaz Üzerinde Beyaz Kare" gibi. Gene soyut geometrik formları, kare ve dikdörtgenleri temel ve nötr renklerle kullanan Mondrian'la da, De Stijl akımıyla karşılaşıyorduk.

\section{Sürrealizm}

Hemen hemen aynı tarihlerde, 1920 öncesinde, G. de Chirico'nun “Metafizik" olarak tanımlanan çalışmalarının da etkilediği yeni bir akım, "Sürrealizm” (gerçek üstücülük) ortaya çıkıyordu. Max Ernst, Rene Magritte, izlemekte olduğumuz "Yanan Zürafa"s1 ile Dali (Resim 47) ve esrarengiz derin mekânların resimleri ile Yves Tanguy bu akımın önemli sanatçılarıydi.

20. yüzyıl başlarında, geçmiş dönem sonlarında Mahler ile başlayan müzikteki değişim, onu izleyen Schoenberg, Webern, Berg ve “oniki ton sistemi”yle yeni bir şekle bürünüyor, konuşmamızın başlarında "Hyperprism"ini dinlediğimiz Varese de bu dönemde ilk bestelerini veriyordu.

20. yy.'ın ilk çeyreğinde, ülkemizde de çok önemli bir gelişme yaşanıyor, Cumhuriyetimiz kuruluyordu. Bunun Batı'ya yönelme hareketi, sanat alanını da kapsıyor, konservatuar açıllyor, "Sanâyi-i Nefise”, "Akademi”ye dönüştürülüyor, resim ve heykel alanında eğitim amacıyla yurtdışına sanatçılar gönderiliyordu. Bunların arasında heykelde Hadi Bara ve Zühtü Müridoğlu, resimde İbrahim Çallı, Hikmet Onat ve Ruhi Arel’i sayabiliriz.

Mimarlık alanında o günlerin en belirgin olayı, yeni başkent Ankara'yı çağdaş bir Batı şehri görünümüne kavuşturmak amacıyla, plânlama ve yapı alanlarında Avrupa'dan uzmanlar, mimarlar getirilmesiydi.

Müzikte ise Cumhuriyetimizin daha ilk yıllarında, çok sesliliğe geçişimizin ilk bestecileri, Adnan Saygun, Hasan Ferit Alnar, Ulvi Cemal Erkin, Necil Kazım Akses, Cemal Reşit Rey Paris’teki öğrenimlerinden dönerek ilk bestelerini vermeye başlıyorlardı.

1. Dünya Savaşı sonrasının siyasi ve ekonomik alandaki sıkıntıları giderek, 1939'da başlayan 2. Dünya Savaşı'nı getiriyordu. Avrupa ve Asya'nın büyük bir bölümünde, yaklaşık 70 milyon insanın ölümüne, büyük yıkımlara neden olan bu savaş, Hiroshima'da, arkasından Nagasaki'de her cinsten, her yaştan yaklaşık 270 bin kişinin birer bomba, "atom bombası" ile yok edilişiyle sona eriyordu. "Soğuk Savaş", çeşitli bölgesel savaşlar, 
siyasal krizler gibi olumsuz, insanın Ay'a ayak basması, "uzayın fethi" gibi olumlu, çarpıcı gelişmelere ait başlıklarla hatırlayabileceğimiz 20. yy.'ın ikinci yarısı, sanat bakımından, hareketli gündemini yitirmiyor, gene mevcut akımların yanında ard arda yeni akımların ortaya çıkışına sahne oluyordu. Önce 1940'larda resimde yeni bir akım, Archile Gorky, Franz Kline, Willem de Kooning gibi sanatçıların öncülük ettiği ve asrın başlarında Kandinsky ile başlayan soyut çalışmalara dayanan "Soyut Ekspresyonizm". Jackson Pollock ise bu hareketi rastlantıya ağırlık verdiği “eylemsel resim"e dönüştürecekti.

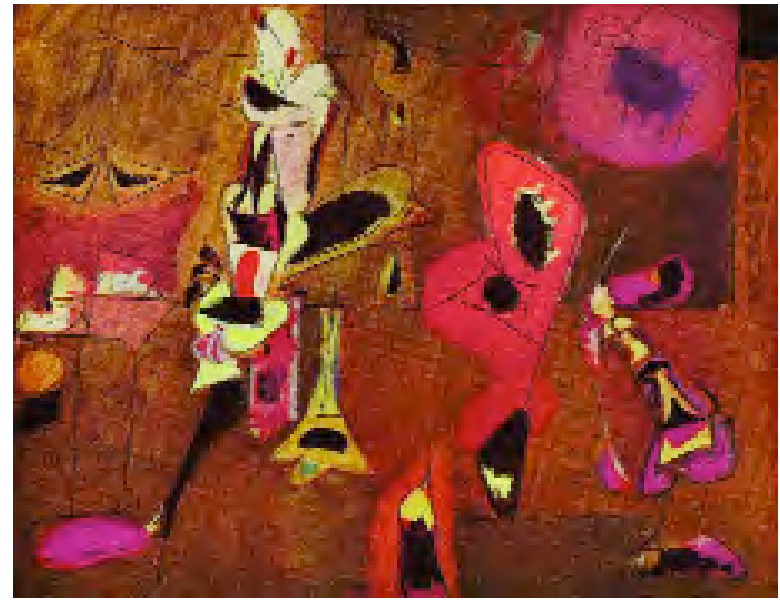

Dönemin müzikteki gelişmesine örnek olarak, burada Gorky’nin “Agony” adlı tablosu eşliğinde (Resim 48) dinlemekte olduğumuz İlhan Mimaroğlu'nun bu resim için bestelediği elektronik eserini gösterebiliriz. John Cage de, 1952'de "en önemli çalışmam" diye niteArchile Gorky, 1947. lendirdiği, üç bölümlü, dört dakika otuzüç saniye süreli, hiçbir sesin bulunmadı̆̆g bir sessizliği “Dört otuz üç” başlığı ile ortaya koyuyordu. Dönemin müzik anlayışı ile ilgili olarak, İstanbul'da 1960'ın sonlarında Goethe Enstitüsü'nde dinlemek firsatını bulduğum, önemli çağdaş bestecilerden Stockhausen yaklaşık olarak şunları söylemişti: “Günümüze gelinceye kadar müzikte tüm imkânlar denendi, formlar kullanıldı. O zaman iki yol kalmıştı, konvansiyonel aletlerle, o güne kadar müzik dışı sayılmış seslerle müzik yapmak veya müzik aleti sayılmayacak bir takım ses gereçleri kullanmak”.

\section{Pop Art}

Sanat akımlarının karşıt sanat akımları yaratmasının bir örneği de "Soyut Ekspresyonizm"e karşı 1950 sonlarında ortaya çıkan “Pop Art”"tır.

Robert Rauschenberg ve Jasper Johns'un olağan eylemleri ve gündelik olanın sıradan ilişkilerini sanatla kaynaştırma çabaları, söz konusu akımı hazırlayan adımlar sayılır. Rauschenberg'in seyirciyi de sanata dahil ettiği doğaçlama performansları, John Cage'in sıradan gereçleri kullanarak ürettiği seslerle yaptığı “Water Walk” gibi müzik gösterileriyle örtüşürken Marcel Duchamp’ın hazır yapımlarını da hatırlatıyordu.

Konusunu yaşanılan günün, yaşanılan ortamın en popüler görüntülerinden alan, reklâm afişlerini, televizyon oyunlarını ve resimli romanları hatırlatan çalışmaları ile olduğu kadar toplum tarafından benimsenmiş sinema sanatçıları ve siyasetçilere ait posterlerle de ilgi çeken Pop Art'ın temsilcileri arasında Richard Hamilton, Andy Warhol, James Rosenquist ve burada bir resmini izlediğimiz Roy Lichtenstein'1 sayabiliriz (Resim 49).

Pop Art ile de ilişkilenen "Postmodern" dönemin tüketim kültürü, sanatın çeşitli dallarına kolay anlaşılırlık, ulaşılabilirlik, akılda kalabilirlik gibi özellikler getirir. "Modernizm"e karşı eleştirel bir tepki olarak beliren Postmodernizm, farklı kültürlere, tarihin farklı dönemlerine, farklı kimliklere

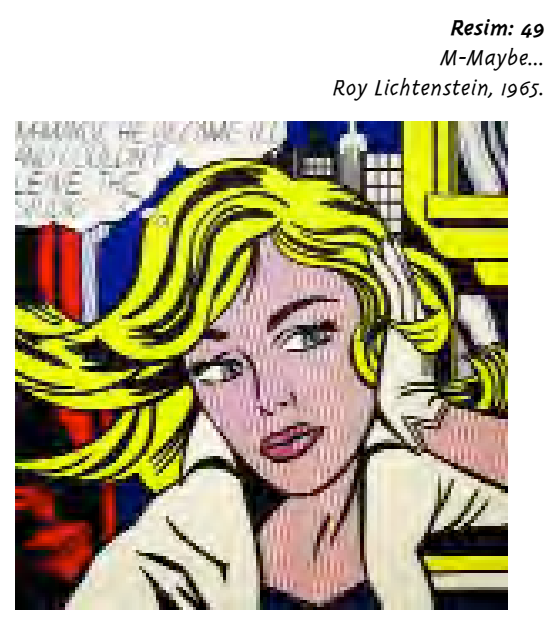


ait çeşitli imgeleri kullanılışlarındaki koşulları göz ardı edip bağımsız şekilde yan yana getirdiği kolajlar üretir. Melezlik, karmaşa, muğlaklık ve çelişki Postmodernizm'in belirgin özellikleri arasındadır. Nitekim Mario Botta'nın görmekte olduğunuz yapısında (Resim 50) ilk bakışta geçmiş dönemlerin yapılarını, örneğin Sullivan'ın yapılarını hatırlatan bir görünüm varsa da cephenin bir kısmını ve taşıyıcılıkta en önemli nokta olan köşeyi parçalayarak ilgi çekmeye de yönelik bir tür ironi gerçekleştirdiği görülmekte.

Resim: 50

Ransila ofis Binası, Son olarak sevgili öğrenciler, sanatçı olun olmayın, sizlere şunları söylemek istiyorum:

Lugano $\mathrm{Bu}$ dinlediklerinizin hepsini hatırlamanızı beklediğimi sanmayın. Hangi dalda öğrenim Mario Botta, 1980 yaparsanız yapın, öğrenim yıllarınız süresince, üniversitemizde bu konuları daha derin-

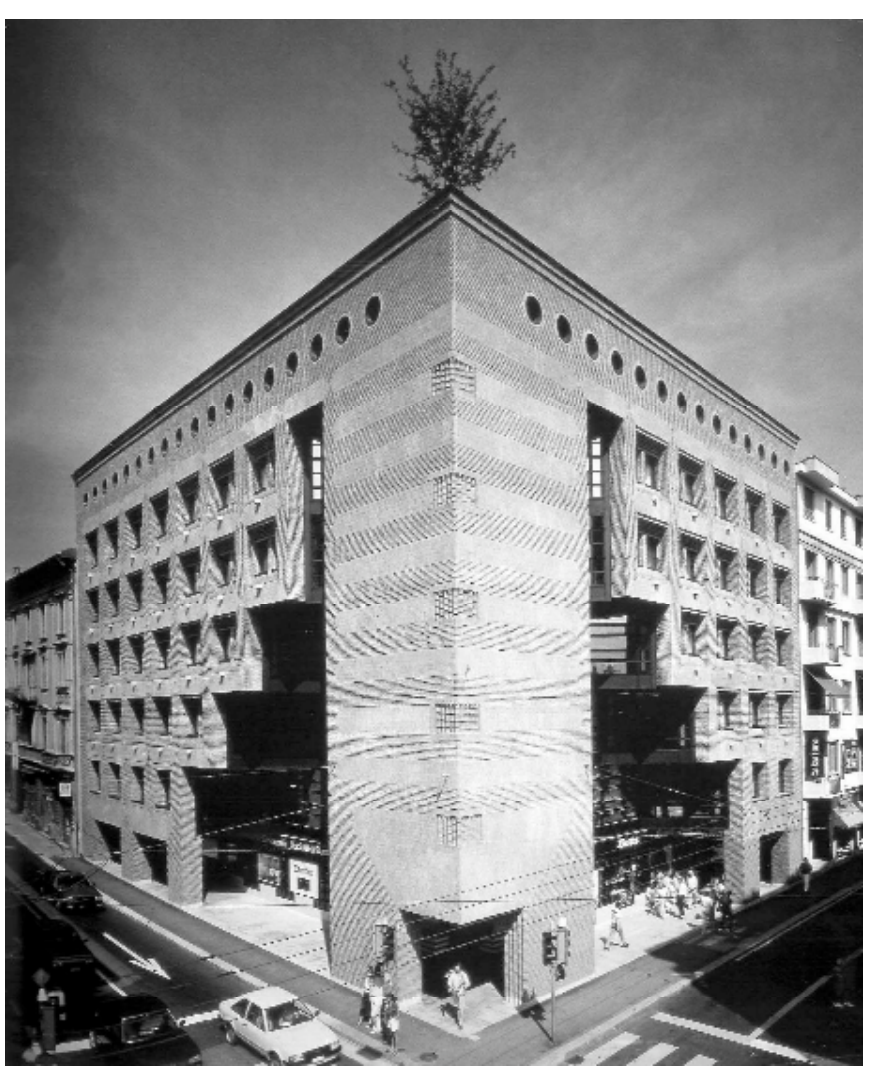

Resim: 50 likli olarak inceleme firsatını bulacaksınız. Ben burada sadece bir giriş yaptım.

Son olarak Viyana'daki Olbrich'in 1889'da tamamlanan "Secession" adlı yapitında, cephede girişin üzerindeki, resimde de okumakta olduğumuz şu sözlere dikkatinizi çekmek istiyorum:

\section{"Der Zeit ihre Kunst der Kunst ihre Freiheit"}

"Zamana kendi sanatı, sanata da özgürlüğüu” anlamında. Kanımca o günden günümüze bu görüş, yalnızca sanat yaratısının değil, değerlendirilmesinin de geçerli ölçütlerinden biri olmuştur ve öyle kalacaktır. Sanatçı olun, sanatınızın yönünü; sanatsever olun, yapacağınız değerlendirmelerinizi bu ilke belirlesin.

Sayın Rektör, yöneticiler, değerli konuklar, sevgili öğrenciler, başarılı bir öğretim yılı diliyor, hepinizi saygi ve sevgiyle selamliyorum 